\title{
PERCEPTIONS OF OUT-OF-FIELD TEACHERS \\ OF THE SUSTAINABILTY OF URBAN TEACHER \\ QUALITY SUPPORT SYSTEMS
}

A Dissertation
presented to
the Faculty of the Graduate School
at the University of Missouri-Columbia
In Partial Fulfillment
of the Requirements for the Degree
Doctor of Education
br. Paul Watkins, Dissertation Supervisor
MAY, 2018


PERCEPTIONS OF OUT-OF-FIELD TEACHERS OF THE SUSTAINABILITY OF URBAN TEACHER QUALITY SUPPORT SYSTEMS

\author{
(C) Copyright by Niketia L. Coleman
}

All Rights Reserved 
The undersigned, appointed by the dean of the Graduate School, have examined the dissertation entitled

\section{PERCEPTIONS OF OUT-OF-FIELD TEACHERS \\ OF THE SUSTAINABILTY OF URBAN TEACHER \\ QUALITY SUPPORT SYSTEMS}

presented by

Niketia L. Coleman

a candidate for the degree of, doctor of education

and hereby certify that, in their opinion, it is worthy of acceptance.

Dr. Paul Watkins

Dr. Sharon E. Gunn

Dr. Odegard Koester

Dr. Charles Phillip Gause 


\section{DEDICATION}

I've heard it said, that we should surround ourselves with people who add to the productivity of our lives. I have been ever so blessed to have been surrounded by people who poured into my life words of wisdom, encouragement and love. These people have stood with me in times of trial and triumph. They have shared in my laughter and my sorrow, wiped my tears and held me up when it seemed I could not stand on my own. At the age of 27 , I suddenly became a single mother of seven, two girls and five boys. It was the wise council of Dr. A.C. Favors and Regina Cotton who encouraged me to enroll in college, not only for myself but for my children and I am eternally grateful for their advice. That advice propelled me on a quest for success, for my family and for countless of children whose lives I would have the honor of touching.

I want to take this opportunity to acknowledge the love and support of my children for they are my purpose. I thank God for our journey together. They have been my strength, my hope, my joy and laughter. My family has been the greatest reward that God has given me. Thank you, Tamica, Charity, Jerry, Jeremy, Jarrod, James and Joshua for believing in me and for the many sacrifices you made over the years as I pursued one academic endeavor after another. I also want to thank my beautiful grandchildren: Kourtland, Jarrod Jr., Nathan, Jayda, Jeremiah, Jordan, Aubree, Jadyn, James Jr., Jalen and Jaela, and who sacrificed their "Nana time," so that I could complete this process.

Lastly I would like to thank my friends and colleagues for their support and encouragement and the experiences we have had that have caused me to grow. First, a very special thank you to Dr. Chauncey E. Granger for your support, guidance, gentle and sometimes not-so-gentle nudging throughout this arduous task. I could not have done this 
without you. Thank you Susan and Dean Cody, Dr. Henry Givens, Jr., Dr. L. Jimerson, Pastor, Dr. R. Griffin, Mrs. A. Strobbe, Mr. G. Ortega Ms. A. Madkins, Dr. P. Hamilton, Ms. C. Hardin Dr. M. Vaughn, Dr. Mary Crockett-Smith for your support. Thank you Ms. Treisa Gladney for your keen eyes and sharp skills; and to my dearest friend of 41 years - Marian Hatch-Ingram, thank you for being the wind beneath my wings. To everyone who has supported me on this journey, I thank you! I appreciate your encouragement and prayers. I am humbled by your love.

In loving memory of James and Mildred Coleman, who gave me life, Cal and Willa Johnson, who loved me unconditionally and gave me vision, Glenn D. Coleman, who gave me hope and Barbara Zoe Harvey who taught me that excellence is without excuses. I pray that I have honored your memories with my life. Rest in peace, I carry you always in my heart. 


\section{ACKNOWLEDGMENTS}

I would like to thank the members of my dissertation committee: Dr. Paul Watkins, Dr. Sharon Gunn, Dr. Odegard Koester, and Dr. Charles Phillip Gause for your support and for sharing your expertise and time during this process. I appreciate your guidance and suggestions in the writing of this dissertation.

I am especially grateful to my committee chairman, Dr. Paul Watkins, for your patience, gentle nudging as well as your sternness when necessary, in keeping me on track. Thank you for your prompt feedback, for helping me to make meaning of my experiences, for listening to my ideas and helping to untangle them. I appreciate the long drives you took to meet with me and for always encouraging me, even when I wasn't sure I wanted to be encouraged. Thank you for believing in me and the worthiness of my subject. Thank you most of all, for not allowing me to give up when "life" continued to happen over and over again. Even in your retirement you continued to mentor me and guide me through this process and I am forever grateful for your commitment to my success. 


\section{TABLE OF CONTENTS}

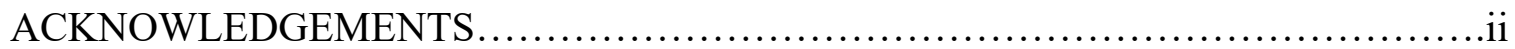

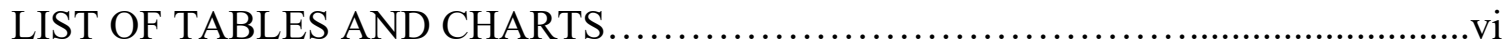

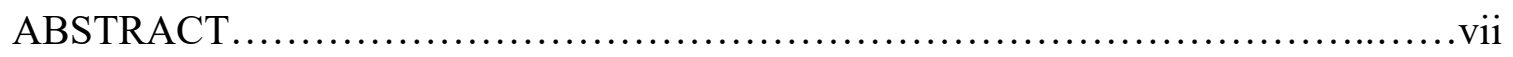

CHAPTER 1: OUT OF FIELD TEACHING: AN OVERVIEW ….................................2

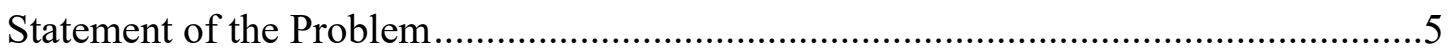

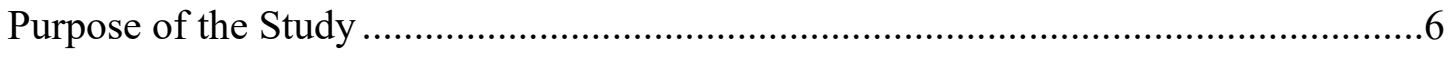

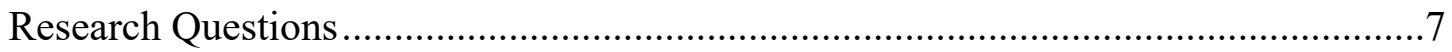

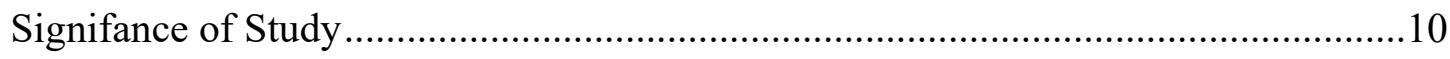

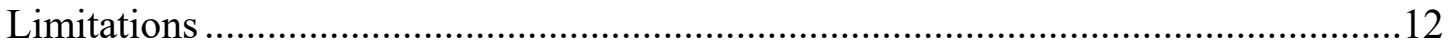

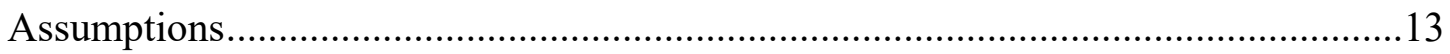

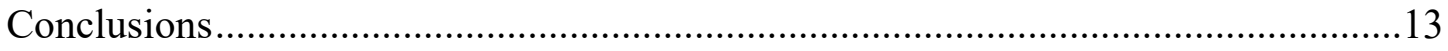

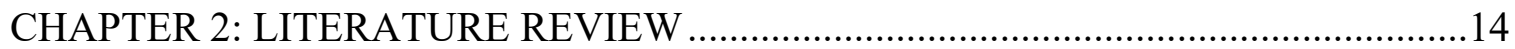

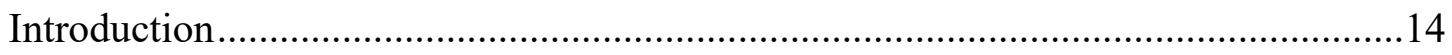

Human Research Theory.................................................................................. 19

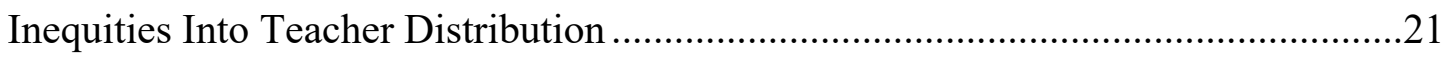

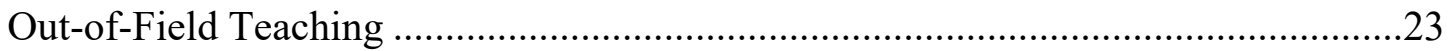

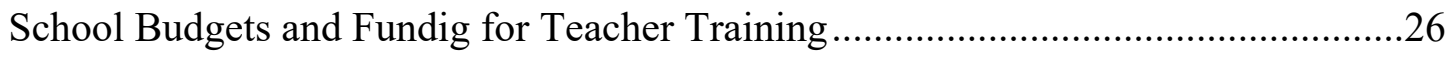

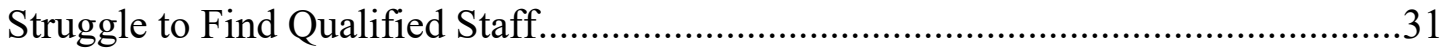

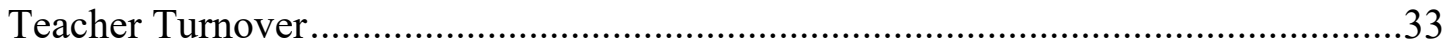

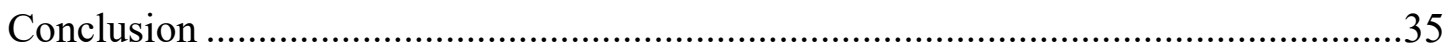




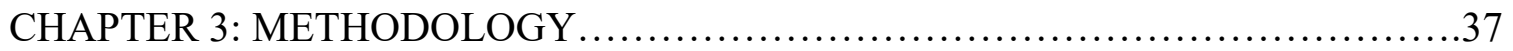

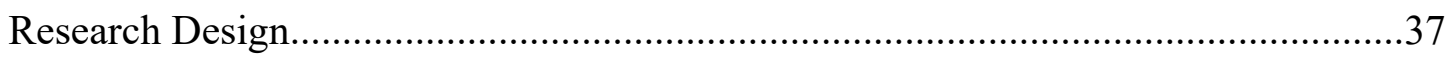

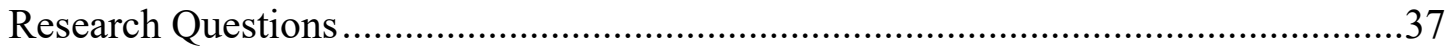

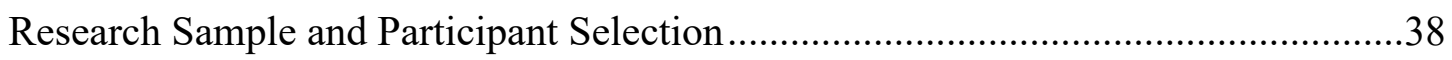

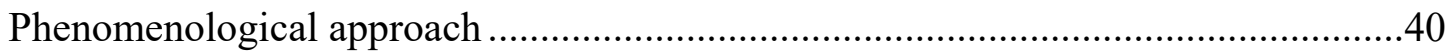

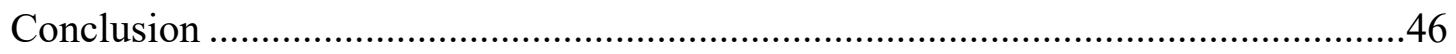

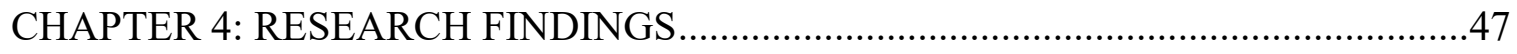

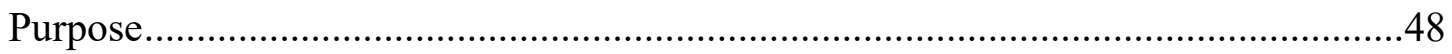

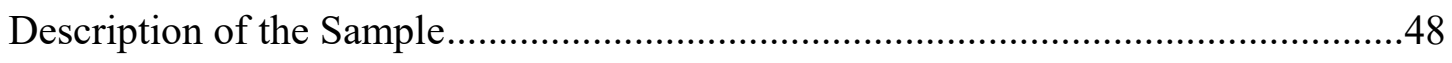

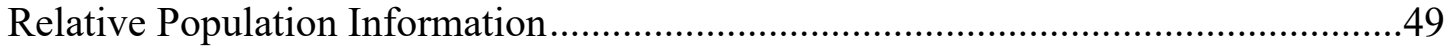

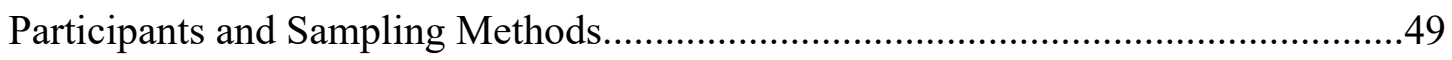

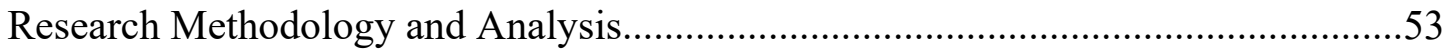

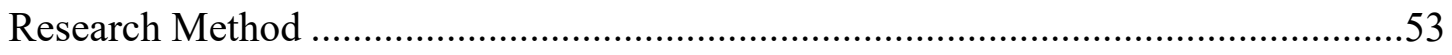

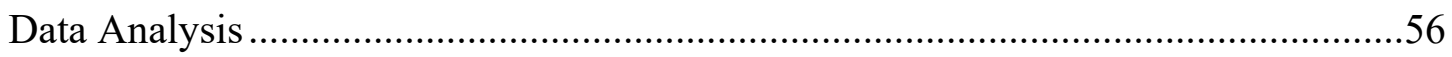

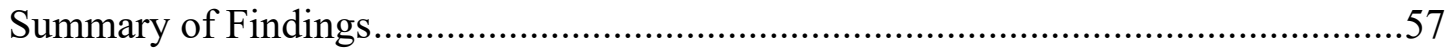

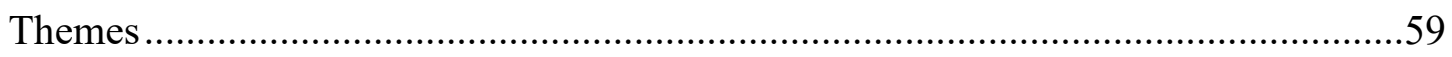

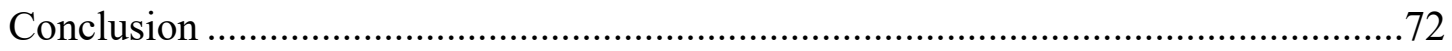

CHAPTER 5: RESEARCH FINDINGS, CONCLUSIONS, RECOMMENDATIONS,

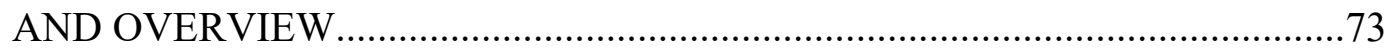

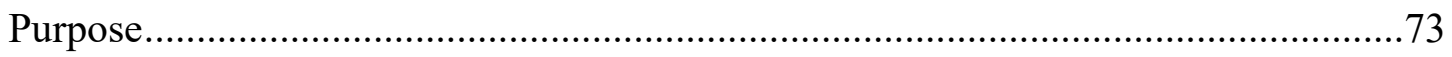

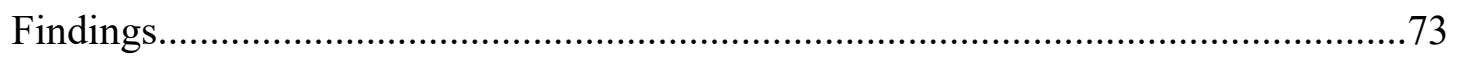

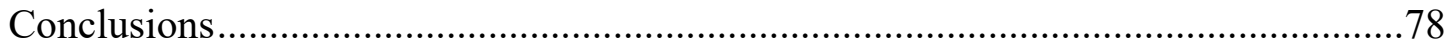




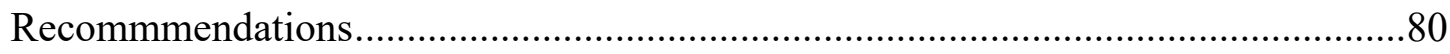

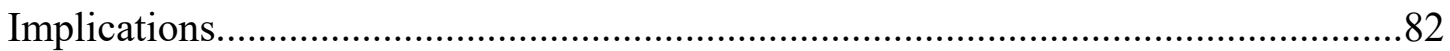

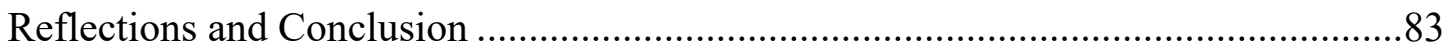

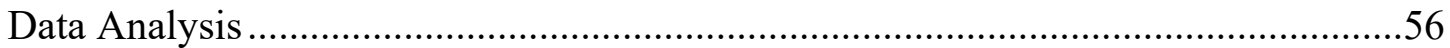

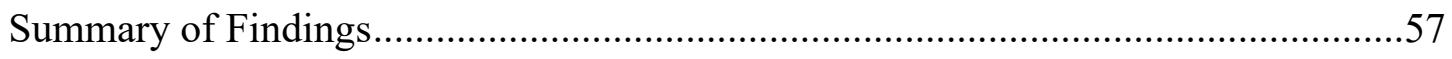

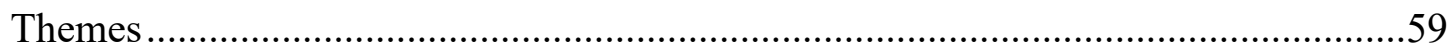

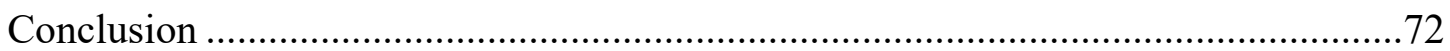

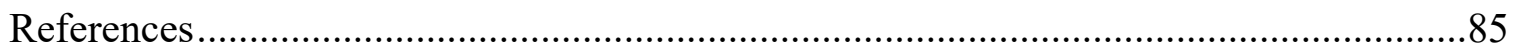

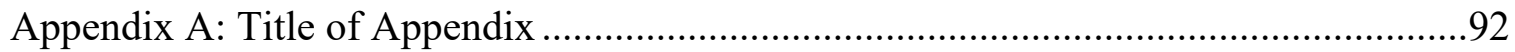

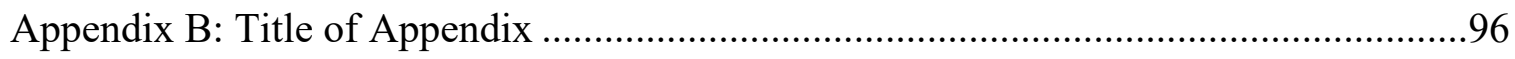

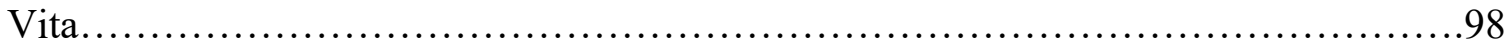




\section{LIST OF TABLES/ CHARTS}

Figure 1. Inductive Logic Approach Flowchart...............................48

Table 1. Support Mechanisms Used By Out-of-Field Teachers......................50

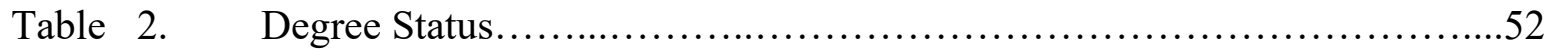

Table 3. Years of Teaching Experience........................................52

Table 4. Out-of-Field Roles/Experiences.................................52

Table 5. Interview Questions Listed by Number and Out-of-Field Teaching Experience...................................................56

TABLE 6 CHARACTERIZED IDENTIFICATION AND PSUEDONYMS

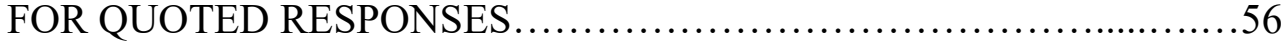




\begin{abstract}
Educational reform movements set ambitious goals for student learning. Numerous factors contribute to students achieving these goals. It has been widely understood that "the increasing emphasis on quality of teaching and learning has placed new demands on staff development, and the search for models and methodologies which are promising for professional development of academic staff has become an important agenda in itself" (Ho, A.,2001 P.35). Effective changes in practice require a great deal of learning on the part of teachers and an even greater amount of support and guidance from administrators (Borko, 2004, Putnam \& Borko, 2000).

Problematic practices in hiring and staffing make it difficult, albeit impossible, to provide an equal distribution of qualified teachers in high poverty districts and schools serving minorities. Contributing to the problem of teacher inequality and underqualified teachers is the phenomenon of out-of-field teaching- a term in reference to certified or qualified teachers who were teaching a subject in which they had no formal qualification or training (Hobbs, 2013). These teachers often receive little training and support and therefore find it difficult to experience success.
\end{abstract}

Through qualitative interviewing this study seeks to explore the perceptions of out-of-field teachers and mentors and understand how they make meaning of their experiences. Five themes emerged from the study: ineffective training and professional development, desire for success, buy in, time, and support.

Teachers and mentors want professional development that is meaningful to the work they do in the classroom. Educators, especially those teaching out-of-field, need 
training that is intense, focused and content oriented. Buy in is vital to any professional training. Out-of-field teachers want to be included in the decision-making as to what professional development they receive.

From this study, it was learned that it is a teacher's priority to make sure they are teaching content standards from day-to-day. The participants identified a lack of support as an inhibitor to that implementation. This concern for the lack of professional support among the participants bares out much of the research (Borko, 2014. Hobbs, 2015, Darling-Hammond, 2002, Ingersoll, 1999). Out-of-field teachers are highly committed to the students and communities they serve. With focused and intense training, close monitoring, time to observe skilled content area teachers, and strong support from building and district administrators, out-of-field teachers can become effective educators when teaching outside their area of expertise. 


\section{Chapter 1}

\section{Teacher Perceptions of the Sustainability of Urban Teacher Quality Support Systems}

Educational reform movements set ambitious goals for student learning. Numerous factors contribute to students achieving these goals. It has been widely understood that "the increasing emphasis on quality of teaching and learning has placed new demands on staff development, and the search for models and methodologies which are promising for professional development of academic staff has become an important agenda in itself” (Ho, A.,2001 P.35).

It is largely believed that improvement in teaching can be achieved through the mastery of basic teaching skills, which include: how to lecture, conduct tutorials, prepare lesson plans, and use media and technology resources (Ho, A. et al., 2001). Many education professionals assume that providing teachers with prescribed skills and teaching recipes will change their classroom practices and improve learning (Ho, A., et al, 2001). Effective changes in practice require a great deal of learning on the part of teachers and an even greater amount of support and guidance from administrators (Borko, 2004, Putnam \& Borko, 2000).

Effective classroom practices that improve student learning are particularly dire in high poverty urban schools where student achievement is lowest. In addition to low student achievement, these schools experience insufficient school budgets, inequities in teacher distribution, low certification standards, little regulation of how teachers are employed, with human resource practices and policies which often impede quality staffing. Likewise, there is often inadequate teacher training programs, few incentives for training and or recruiting, and a shortage of qualified teachers in low-income minority 
schools (Jacob, B., 2007, Peske, H.G \& Haycock, K.2006). These challenges make it difficult to provide teachers with the support systems they need to be successful. Therefore, many teachers abandon impoverished, urban districts with high minority populations in search of employment in more affluent districts or leave the profession altogether (Ingersoll, 2002, Haycock, K. 2006).

Teacher attrition rates in the United States are high, $40 \%$ of new teachers leave the profession within the first five years (Ingersoll, 2002, Rinke, 2011, Haycock, 2002, Wong, 2004). While there may be debate as to whether there is a nationwide crisis in teacher retention, it is clearly evident that urban high schools are particularly susceptible to high attrition (Rinke, 2011). As impoverished urban districts struggle to attain and retain quality educators, the variables that impact their efforts create boundaries that impede effective teacher quality support systems.

This realization has lead educational policy makers to demand professional development opportunities for teachers that will help them enhance their knowledge, develop new instructional practices, and stay in the classroom to improve student learning (Borko, 2004). For example, the No Child Left Behind Act of 2001 requires that states ensure the availability of "high quality" professional development for all teachers but it does not clarify what constitutes as high quality professional development or how it should be made available to teachers (Borko, 2004). Another example of policymakers' demand for helping teachers to succeed is the Teaching Commission's Teaching at Risk: A Call to Action (2004). This report proposes a multifaceted approach which includes ongoing professional development and high standards for teacher classroom performance and student achievement. Still there is no clear definition as to the content and character 
of that professional development. What is clear is that the professional development that is currently available to teachers is woefully inadequate. "Each year, schools, districts, and federal government spend millions, if not billions of dollars on in-service seminars and other forms of professional development that are fragmented, intellectually superficial, and do not take into account what we know about how teachers learn"(Borko, 2004 p. 13). According to Sykes (1996), the inadequacy of professional development is "the most serious unsolved problem for the policy and practice in American education today" (p.465).

Contributing to the problem of teacher inequality and underqualified teachers is the phenomenon of out-of-field teaching. Described as “education's dirty little secret" in 1990, the label out-of-field teacher had been used since the early 1980's in reference to certified or qualified teachers who were teaching a subject in which they had no formal qualification or training (Hobbs, 2013). The term is more widely used with middle and or high school teachers of students $12-18$ years of age. Content areas most affected by out-of-field teaching are mathematics, English and Social Studies (Haycock, 2006, Ingersoll, 2009). The percentage of underqualified teachers in high poverty and rural school districts mirror the national average of 33 percent.

There is a wide disparity in teacher distribution across regions, states, and districts. A disparity which can be explained by low salaries and poor working conditions in impoverished districts. Shortages that exist are not due to a shortage of manpower, but a shortage of teachers willing to work at the meager salaries and under the strenuous working conditions existing in less affluent locations. States and districts that offer more lucrative salaries and better support for teaching and education have a surplus of qualified 
teachers. Simply put, better-funded districts recruit the best-qualified teachers (National Commission on Teaching and America's Future, (NCTAF) 2002). Unlike the field of medicine, there are few policies at the national level that ensure that the federal government will step in and offset shortages by funding needed training and scholarships for candidates in shortage areas of education (NCTAF, 2002).

The problem of out-of-field teaching is aggravated by antiquated hiring practices and procedures. These cumbersome practices often chase away highly qualified candidates because of inefficiencies in policy and procedures which are often long and drawn out. Human resource practices and policies which impede quality staffing coupled with a shortage of qualified teachers in low-income minority schools, make it difficult to provide teachers with the support systems they need to be successful. Thus many teachers abandon impoverished, urban districts, with high minority populations and seek employment in more affluent districts (Jacob, B., 2007, Peske, H.G., \& Haycock, K., 2006).

Schools and Staffing Survey (SASS) data suggests that the way schools and teachers are managed contribute to the problem of out-of-field teaching. (Ingersoll, 2000). The appointment and allocation of teaching assignments is a decision that is usually made by school principals. It is often left to the building level administrator's discretion who will teach which courses. In other cases, teachers with seniority often have the right to choose who and where they teach, as district policies gained through collective bargaining reward senior, better-educated teachers the right to transfer to easier schools which have the most advanced students (Haycock, 1998). 
In addition to collective bargaining agreements which inadvertently place underqualified teachers in high-poverty, low achieving schools, building level administrators are often charged with the task of staffing schools while operating under tight budget constraints with few regulations as to how teachers are used, therefore school principals often cut expenses by assigning teachers to teach outside their field (Ingersoll, 2002).

\section{Statement of the problem}

The contemporary educational theory holds that one of the major causes of inadequate student achievement in disadvantaged schools is the inability to attain highly qualified staff and provide adequate support to develop skilled teachers who remain in the profession and who will serve in high poverty, minority, urban areas where they are needed most. (Haycock 2001) While there has been much focus on teacher quality support systems, there is still uncertainty as to the sustainability and effectiveness of these systems and their contributions to student success. Authors (Haycock, 1998, Darling-Hammond, 2001, Ingersoll, 1999), document a clear relationship between low standards, low-level curriculum, ineffective teachers and poor student achievement. Teachers are the most significant factor in student achievement; therefore, improvements in teacher training programs, teacher quality supports, and teacher assignment patterns are critical to the education of poor and minority students (Haycock, 1998).

Because there are a shortage of qualified teachers who are willing to teach in less affluent areas with large minority populations, administrators of these districts must develop qualified, effective teachers through continued educational opportunities, internal 
and external network support and sustainable teacher support systems (Borko, 2004, Jacob, 2007, Darling \& Hammond, 2001) In 2002, the federal government outlined a plan that would allow states to draw from almost $\$ 3$ billion in Title I and Title II funds to meet the "highly qualified" teacher mandates (Berry, B. 2004). The plan emphasized strategies that included signing bonuses and merit pay as well as recruitment of nontraditional candidates. Further strategies also included new teacher induction programs; research-based professional development and alternative certification (Berry, B., 2004).

\section{Purpose of the Study}

The purpose of this study is to examine, through the lens of phenomenology, the teacher lived experiences with professional development support systems and their impact on teacher retention in urban schools. This study will identify the support practices and professional development program opportunities for urban Missouri school districts under pressure from the State to improve student achievement and raise standardized test scores. This study seeks to analyze those practices and programs and their sustainability as perceived by teachers.

While not the focus of this research, school and school district practices, policies, characteristics, and conditions provide a backdrop to teacher improvement, affecting the ability to staff classrooms with qualified out-of-field faculty. The focus of this study seeks to understand how participating in professional development impede or promote quality teaching through participation and engagement with the district's learning practices. This study examines the perceptions of out-of-field teachers and how those perceptions shape the effectiveness and sustainability of quality support systems. 
Examination of the staff development practices of urban districts will focus on the commitment of under-qualified and struggling staff members to seek coursework, professional development and training to become more qualified as well as the commitment of the school and district leaders to provide support for these individuals (Bolman \& Deal, 2007, Lepak \& Snell, 1999, Shafritz, Ott \& Jang, 2005). Furthermore, this study seeks to evaluate the practices and strategies teachers use to understand and execute their responsibilities, organize their work and attain objectives. This study will explore resources and external activities sought by school districts and individuals to enhance teacher performance.

Problematic practices in hiring and staffing make it difficult, albeit impossible, to provide an equal distribution of qualified teachers in high poverty districts and schools serving minorities. Yet, students in these schools need quality educators perhaps more than their suburban neighbors. This study will examine efforts schools and school districts take to provide sustainable internal and external professional development for quality teacher support systems in an effort to develop highly qualified educators through a system of sustainable supports. This study will examine support systems available for teachers in impoverished urban schools and districts and capture their perspectives of such.

\section{Research Questions}

The research questions guiding this study are:

1. How do urban, out-of-field teachers and mentors perceive the quality of their school districts' professional development efforts? 
2. How do urban out-of-field teachers and mentors contribute to the sustainability of professional development in their schools?

3. How do urban, out-of-field teachers and mentors understand their contribution to the sustainability of teacher developmental support systems in their school?

\section{Conceptual or Theoretical Framework}

The organizational analysis framework guides this study, using the human resource and adult learning frame as a lens to view the phenomenology of selecting and providing sustainable teacher quality support systems and the contributions to student success on urban school districts with large minority populations and low student achievement. Modern behavioral scientists focus their attention on how organizations could and should allow and encourage their members to grow and develop. Human resource theory draws on a body of research and theory built around four basic assumptions: 1.) Organizations exist to serve the needs of people. 2.) Organizations and people need each other. 3.) A poor fit between the individual and the organization will lead to exploitation on the part of both. 4.) A good fit benefits both the organization and the individual. (Shafritz, Ott \& Jang, 2005, Bolman \& Deal, 2009).

Bolman and Deal (2009) assert, "Our most important asset is our people" (p.116). Organizations must choose members who are a good fit for the organization, then work to keep them. To analyze an organization one must look at how it chooses its members and what it does to sustain their professional health. In the book "Good to Great Why Some Companies Make the Leap...and Others Don't', Jim Collins (2001) contends that goodto-great leaders "first got the right people on the bus, the wrong people off the bus, and the right people in the right seats..." (p.13). He believes that the right people are the most 
important assets. For Collins, a good fit would mean to have members operating in their strengths, using them where and how they are most beneficial to the organization.

This study looks at the perceptions of teachers and mentors on the sustainability of teacher quality support systems. The human resource frame focuses on how organizations and people serve each other. Bolman and Deal (2009) maintain that "people and organizations need each other" (p.122). Organizations need skilled, talented people with fresh and innovative ideas. People need careers with lucrative salaries and opportunities to advance. When there is a good fit, both parties benefit. In order to have a good fit; organizations must consider how they respond to members' desires to have meaningful work, autonomy, and a salary commensurate to the duties they perform and which allows them a comfortable lifestyle. Collins cited several business leaders who used his approach to getting the right people on the bus. He believes that the right people will not need to be tightly managed or fired up, they will be self-motivated by the inner drive to produce the best results (Collins, 2001).

In his work, From Good to Great: Why Some Companies Make the Leap and Others Don't (2001), Collins cited Wells Fargo, 1970 CEO, Dick Cooley and his chairman Ernie Arbuckle, and their focused effort of "injecting and endless stream of talent," directly into the veins of the company (p.42). Collins stated that these successful businessmen hired outstanding people whenever and wherever they found them, without any specific job in mind. "If I'm not smart enough to see the changes that are coming, they will. And they'll be flexible enough to deal with them" (p.42). Collins believes that it is this flexibility that makes an employee a good fit. "Wells Fargo's approach was 
simple: you get the best people and you build them into the best managers in the industry..." (p.43).

All human resource strategies rest on six basic principles: Organizations must develop a shared philosophy for managing human capital and build practices to implement that philosophy. Organizations must hire the right people; they must be selective and know what they want then reward members well and provide job security, competitive salaries, and other benefits. Organizations must invest in its members through professional development opportunities. Organizations must empower members by providing information and support, grant autonomy and welcome participation in decision making. Finally, organizations must promote diversity and hold leaders responsible (Bolman \& Deal, 2009, Shafritz, Ott \& Jang, 2005, Del Favero, M., 2003).

\section{Significance of the Study}

This study is significant as it focuses on out-of-field teaching — teachers assigned by school administrators to teach subjects for which they are not qualified, subjects that do not match their certification or training. Urban education can be messy and recruiting qualified teachers to low income high crime neighborhoods to launch a career can be more aspiration than reality (Darling-Hammond, 2001). Ingersoll (2002) states, "This is a crucial factor because highly qualified teachers may actually become highly unqualified if they are assigned to teach subjects for which they have little training or education" (p.2). This phenomenological study will provide a narrative of the perceptions and needs of out-of-field teachers and of the professional development and support systems that will enable them to do their jobs more effectively. This body of work is important in that it is derived from the perspectives of those working in the field of education and captures the 
perspectives of individuals who address the problems of out-of-field teaching on a daily basis.

This study draws from the experiences of teachers who are best qualified to answer the question of what support systems are needed to best enhance teacher performance. Further, the inquiry may provide those responsible for hiring, an opportunity for discourse and for reflecting upon current practices and policies that impede acquisition and retention of highly qualified educators. This work may inform hiring practices, teacher placement procedures, and professional development for underqualified educators as well as incentives for maintaining qualified staff. It may also inform mentoring and professional development practices as well as certification practices.

\section{Definition of Terms}

Induction: According to Wong (2004), Induction is a process-a comprehensive, coherent and sustained professional development process - that is organized by a school district to train, support and retain new teachers and seamlessly progresses them into a lifelong learning program.

Mentoring: Mentoring is an action, by a single person- a mentor to help a new teacher. Typically the help is to assist the teacher in survival, not sustained professional learning which helps a teacher develop expertise in his or her craft (Wong, 2004).

Mentor: A single person- assigned to help a new teacher 
Mentee (new) teacher: teacher possessing an Initial PC classification certification granted by the Department of Education of the state (dese.mo.gov.2016).

Initial PC “a four-year license requiring two-years of mentoring, annual evaluation, participate in a beginning teacher assistance program, have a professional development plan, and a total of 30 contact hours of professional development over a period of four years. (dese.mo.gov.2016)

Out-of-Field Teaching: teachers assigned by school administrators to teach subjects for which they are not qualified, subjects that do not match their certification or training. Ingersoll (2002). "Qualified or certified teachers (usually) teaching a subject for which they have no formal qualification.” (Hobbs, 2013. P1)

In-field (core academic) teacher: teachers who possess a minor or major and a teaching qualification (including a teaching method) in that subject (Hobbs, 2013).

Scientific reduction is a process to counteract biasness when performing qualitative phenomenological research. The researcher categorizes information by participants as fresh and new experiences (Giorgi, 2009).

Imaginative variation is to seek possible meaning using imagination, frames of reference, roles, and different perspectives (Moustakas, 1994).

\section{Limitations}

Because this is a qualitative (evaluative) study, a limited number of participants' information will be gathered on the perceptions of first and second-year teachers from the St. Louis area. Another limitation to this study is that some of the participants may not 
have experience in the field of human resource management as it relates to education and therefore their decision making processes in the hiring practices of education are limited.

\section{Assumptions}

One assumption, when approaching this research, is that the school district is familiar with the problem of out-of-field teaching, yet continues to hire/place underqualified teachers in the classroom. It is important to be familiar with state mandates as well as district policies and practices and have firsthand experience with the problem. With such proactive behaviors it is important that an issue is fairly and adequately reported and areas of concern for support systems for under-qualified teachers are clearly identified. Another assumption is that school districts are implementing and monitoring teacher induction and mentoring programs.

\section{Conclusion}

One-third of core teachers in low-income, high poverty school districts are unqualified or under-qualified to teach the classes to which they are assigned. The immediate perception is that there is a shortage of qualified teachers. A closer look reveals that school/district hiring practices and policies, as well as salary and benefit packages, also impact their ability to obtain qualified teachers. Urban districts are unable to compete with more affluent school districts in better neighborhoods with schools that experience high student achievement levels.

This study will report the perceptions of teachers on support systems available to them. It will use a phenomenological lens to describe meaning for several individuals and their lived experiences as a mentee and out-of-field teachers in an urban setting. 


\section{Chapter 2:}

\section{Review of the Literature}

The mission and purpose of any school is the success and achievements of its students. All efforts must be directed to improving student achievement. The person who is ultimately responsible for this task is the teacher. What the teacher knows and does in the classroom is the determining factor in improving student achievement. Substantial evidence shows that teacher qualification is linked to student achievement (Wong, 2004). Wong agrees with Darling-Hammond and Youngs (2002), who state, "Studies that use value-added student achievement data have found that student achievement gains are much more influenced by a students assigned teacher than other factors like class size and class composition" (p. 41). In his article, “The Six T's of Effective Elementary Literacy Instruction, Richard Allington explains what he believes matters most in teaching children to read, effective and expert teachers. He contends that good teachers manage to produce better achievement regardless of which pedagogical approach, curriculum materials or reading program selected (Allington, 2003). According to Allington (2003), if we are to truly improve student achievement and attain the goal of no child left behind, we must invest in effective teaching, whether in hiring decisions or professional development planning. Having an effective teacher instead of an average teacher for 4 or 5 years in a row could essentially close the gap in math performance between students from both low income and high income households (Wong, 2004). This, he says is the most research strategy available (Allington, 2003). He further insists that school administrators must craft policies that ensure that an increasing number of effective teachers are produced in their schools every year. School systems must have an effective teacher induction program if they are to produce quality effective teachers. 
Wong defines induction as a system-wide, coherent, comprehensive training and support process that continues for two or three years and then seamlessly becomes part of the lifelong professional development program of the district to retain new teachers and keep them teaching and improving toward increasing their effectiveness (Wong, 2004). In his article, Induction Programs that Keep New Teachers Teaching and Improving, Wong explains the difference between induction and mentoring.

The words mentoring and induction are often used synonymously (Isreal, M., Kamman, M., McCray, \& Sindelar, P. 2014), however, they are not synonymous and thus are often used incorrectly. According to Wong (2004), Induction is a process-a comprehensive, coherent and sustained professional development process - that is organized by a school district to train, support and retain new teachers and seamlessly progresses them into a lifelong learning program On the other hand, mentoring is an action, by a single person- a mentor to help a new teacher. Typically the help is to assist the teacher in survival, not sustained professional learning which helps a teacher develop expertise in his or her craft. For teachers in their first year of teaching, there are two types of mentoring support. The first, psychological support addresses are pressing personal and emotional needs, while instruction related support provides teachers with skills to tackle the more basic challenges of instruction. A mentor is a valuable component of the induction process, however, mentoring is not induction (Wynn, Carboni, \& Patall, 2007, Wong, 2004). Mentoring is a part of the induction process, aligned to the district's mission, vision and structure in order to be effective. Mentors must be used in combination with the other components of the induction process and trained to the mission and goals of the district (Wong, 2004). 
Induction programs must be comprehensive, including professional learning and provide opportunities for collaboration, according to a study done by Britton, Paine, Pimm \& Raizen (2003), induction programs in Japan, China, Switzerland, France and New Zealand. The "induction approaches must be highly structured, comprehensive, rigorous, and seriously monitored" (Wong, 2004). Professional learning is a lifelong process which delivers growth and professionalism to teachers through an organized, sustained professional development system. In each of these countries, collaboration was a key component, as collaborative group work is a vital part of the teaching culture of the five county surveyed. It is the function of the induction phase to engender collaboration through shared experiences, practices, tools and language among all colleagues and to treat new teachers as colleagues and cohorts (Wong, 2004).

Wong (2004) contrasts the practices of schools in the U.S., stating that isolation is a common thread and complaint among new teachers. Many new teachers voice concern about not being granted time to observe another classroom. These teachers say that they are not given the opportunity to observe other teaching styles, even that of their mentors, and thus are unable to glean from the effective, creative practices of other teaching professionals. Wong (2004) and Allington (2003) contend that educators must move beyond mentoring to comprehensive induction programs if they are to redesign professional development (Wong, 2004).

According to a post-induction survey, Investing in Our Future, 186 beginning science and math teachers, Luft and Cox (2001), suggests that "beginning teachers overwhelmingly regard having interactions and feedback from mentors as important support for their learning to teach science and mathematics. The more often 
that beginning teachers had lessons observed and discussed by their mentors, the higher they rated their induction programs" (p. 138). In an analysis of formal and informal weekly journals written during a semester by first-year teachers, Johnson and Bowman concluded that what beginning teachers value most is the opportunity to observe and be observed by others (Wang, Odell \& Schwille, 2008).

The inability to observe effective teaching techniques is one concern of new teachers. Still another concern is that as preservice teachers in university classrooms, they do not have the chance to interact positively with children from culturally diverse or urban backgrounds. Because of limited interaction, the cultural biases they bring with them might never be directly challenged. Beginning teachers thus have little awareness of the histories, strengths, resources, and accomplishments of the communities they are entering (Leland, C. and Murtadha, K., 2011). Leland and Murtadha (2011) who are professors in the Department of Literacy, Culture, and Language Education and the Department of Education and Policy Studies at Indiana University-Purdue University contend that many university students are white females, who do well in school and who see teaching as "something requiring a little more than a love for children and an affinity for "doing school" (p.896). The authors report that in the journal that these teacher candidates keep, they see many reports about treating all students the same and not seeing color. This cultural discourse includes the naïve assumption that students in their future classroom will be/look just like them and that to be successful, they only need to follow in their own favorite teacher's footsteps (Leland \& Murtadha, 2011). 
Unfortunately, these teacher candidates often see the teacher education program as unnecessary. As many of them had voiced their concerns when they entered the program saying, "I don't know why I have to go through this whole program just to get a license, I've had my own Sunday school class for years and I already know how to teach (p.385.)" They are even more unhappy when they discover they will be going to city schools and working with culturally diverse populations. These pre-service teachers complained of having to spend so much time in "deficient" urban schools. Their real-life experiences in urban schools were reinforced when their college courses were taught on the campuses of urban schools in dangerous neighborhoods and in less-than-ideal conditions Leland \& Murtadha, 2011).

After spending considerable time in these underprivileged urban settings, which they complained about, surprisingly, many teacher candidates sought out and accepted positions in the very communities they once saw as deficient. This transformation in belief is not a random occurrence. Some experiences or set of experiences in their teacher education program changed their beliefs and their cultural discourse. Leland and Murtadha cite Haberman, saying, that effective multicultural teacher education involves selecting participants who are predisposed to multiculturalism and on a situation-specific basis as they function in their role as teacher (Leland \& Murtadha, 2011) Preservice teaching programs must address cultural stereotypes in order to debunk myths that communities of color have nothing worth knowing or building on and are inferior to what man teacher candidates know- their own White norms. Having experiences that highlight the strengths of diverse learning can make a big difference, yet it is not enough. If urban school districts are to retain a quality teacher, induction 
programs must include and induction into the community. Aside from spending extensive time in K-12 classrooms, they must also visit grocery stores and barbershops in the community as well as spend time observing in community organizations. These experience change their discourse from "What is wrong with these students and their families?" to "How can I teach so that the needs of these students are met and they can learn?" Leland and Murtadha go on to say that "teachers need to have experiences that cause them to become reflective and analytical about their practice" (p.903). One way they believe to do this is through writing and reflecting about their practices and whether enhance or impeded learning. This approach is in stark contrast to the "sit and get" model of professional development which requires participants to sit and listen to experts expound on some new approach, technique or theory. This method implies that knowledge is something that can be transferred from one individual to another. Although listening to professionals can be entertaining, there is little evidence that it is transformative in terms of affecting teacher performance. Induction must include professional development that helps teachers create possibilities for the production or construction of knowledge (Leland \& Murtadha, 2011).

\section{Human Resource Theory}

Lepak and Snell (1999) who draw on the human capital theory identify four modes of employment: internal which includes development and acquisition and external which encompass contracting, and alliance. Internal development is the mode wherein employee skill base is built through training and development initiatives, as in professional development for educators. Internalization is beneficial as it allows 
organizations a method of more effectively monitoring employee performance as in teacher performance-based evaluations. Internalization answers the question of what an organization is willing to do to sustain its members. What will professional development opportunities it make available so that members can acquire the training and skills needed to optimize performance, thus making it possible for the organization to accomplish its mission (Lepek and Snell, 1999)?

The external mode includes workers such as contract employees or as in the field of education, those expert individuals and organizations offering professional development and training to educators but are not part of the educational system. Graduates are not from the field of education but may be considered subject-matter experts. The external mode requires the organization to form alliances with outside entities and partner with those individuals to develop quality professionals within the organization. While some theorists espouse one theory and others the latter, the benefits of internal employment include greater stability, better coordination and enhanced socialization and prevention of costly external training programs. (Lepak, D., \& Snell, S., 1999). Lepak and Snell contend that the external mode benefits the organization as it may enable organizations to decrease overhead and administrative cost. Lepak and Snell argue that discourse should not be reduced to an either/or distinction of employment modes, but rather that these forms should be used simultaneously 


\section{Inequities in Teacher Distribution}

According to the Coleman report of 1966, Education once held the belief that what students learned was largely determined by their families' socioeconomic backgrounds. Educators believed that regardless of what schools did, children from lowincome families whose parents held low levels of education simply would not learn very much. (Haycock, 2002, 2003). The Coleman report argued that children from more affluent and better educated homes would excel. Recent research has turned this thinking upside down (Haycock, 2002). Educators now believe, and research has proven that what schools do make a huge difference in whether students learn and that good teaching matters most. Haycock quotes a paper prepared for the National Bureau of Economic Research saying, "The results show large differences among schools in their impact on student achievement. These differences are centered on the differential impact of teachers, rather than the overall school organization, leadership, or even financial condition." (Haycock, 2002, p.12) The challenge, therefore, is to ensure that students from low-income, low-leveled educated homes are taught by highly qualified educators.

Haycock (2002) and Ingersoll (2009) agree that there is a wide disparity of qualified teachers in high-poverty and rural school districts. The percentage of underqualified and unqualified teachers in these districts mirror the National average of $33 \%$ (Haycock, 2006; Ingersoll, 2009). These districts which often face critical circumstances of poor student achievement and the loss of state accreditation, find it difficult to attract and retain high-quality teachers. Stress, poor working conditions, and low pay are reported as the top three reasons for leaving the profession or choosing more affluent school districts. Other reasons include lack of support, bureaucracy, little or no financial 
incentives, and growing job demands (Darling-Hammond, L., 2001; Haycock, K., 2006; Ingersoll, 1999).

Low-income and disadvantaged schools in impoverished areas have more out-offield teachers in core subject areas than most other kinds of schools (Ingersoll, 1999). Ingersoll reports that over one-fourth of all secondary students enrolled in math classes are taught by teachers who do not have a college minor in math or a related discipline, the same holds true for secondary English classes. Ingersoll (2001) goes on to say that onefifth of secondary social studies teachers lacks a minor in any of the social sciences or public affairs, history or social studies education. It is critical that these individuals receive additional training and support to enhance their knowledge and skill base to increase their effectiveness as educators (Haycock, K., 1998, Ingersoll, 2002).

In her research, Haycock found that when taught by the least effective teachers, low-achieving students gained close to 14 points each year on the state test. However, the same students gained more than 53 points when taught by the most effective teachers. Teacher quality also made a difference for middle and high-achieving students (Haycock, 2002, 2003). The impact of teacher effectiveness appears to be cumulative, students who had highly effective teachers for three consecutive years scored more than 50 percentile points above students who had three underqualified teachers consecutively. These differences can represent the difference between remedial and gifted placement and entry into a selective college or a minimum wage job (Haycock, 2002, 2003).

In acknowledging the unfair distribution of qualified teachers and their pivotal role in student learning, education professionals also must acknowledge that poor and minority students continue to fall behind their white counterparts. National measures of 
student achievement illustrate a clear indication of the devastating results of the inequities of quality teacher distribution. The National Assessment of Education Progress reveals that two-thirds of Latino and African American $4^{\text {th }}$-grade students perform below the basic level in reading compared to 28 percent of white students. The percentage of white students scoring below basic in mathematics is about 22 percent as opposed to 53 percent Latino and 62 percent African American. By the completion of high school, these minority students have skill sets in math and reading that are identical to white students at the middle school level (Haycock, 2002, 2003, Ingersoll, 1999, 2000, National Center for Education Statistics, 2000, Cook, L., 2015).

\section{Out-of-Field Teaching}

There is a growing national and international interest in out-of-field teaching teachers assigned to teach subjects for which they have little education or training. Because it is often difficult to staff urban schools, many teachers are assigned to teach classes they are not qualified to teach. These teachers teach outside of their field of study or expertise this makes the need for content area professional development crucial to their success (Ingersoll, 2002, Jacob, 2007). Teachers must have an organized, rigorous, professional development system. This is an important, but long unrecognized, the problem in schools. The reasons behind this phenomenon stem from insufficient school budgets, inequities in teacher distribution due to policies surrounding tenure and teacher choice, low certification standards, little regulation of how teachers are employed, inadequate teacher training programs, few incentives for training and or recruiting, and a shortage of qualified teachers in low-income minority schools (Ingersoll, 2002). For years, the nation's lowest-performing schools have faced dire shortages of minimally 
qualified teachers. Therefore, these districts are forced to continue to employ teachers who are un-credentialed and teaching outside of their field of expertise (Futernick, 2010).

Current literature reveals that $30 \%$ or more of secondary core classes, mathematics, physical science, special education, and bilingual education are taught by teachers who are not certified to teach the classes they are assigned (Darling-Hammond, 2001, Haycock, K. 1998, Haycock, K, 2003, Ingersoll, 1999). Mis-assignments occur when there are not enough qualified teachers to teach core subjects of math, English or science, because district administrators must choose from a pool of underqualified teachers (Futernick, 02010). The authors document a clear relationship between low standards, low level curriculum, undereducated teachers and poor student achievement. Teachers are the most significant factor in student achievement (Whitehurst, 2002) therefore, improvements in teacher training programs, teacher assignment patterns, and recruitment are especially critical to the education of poor and minority students (Haycock, 1998; Darling-Hammond, 2001,).

Concern with the quality and qualifications of teachers are neither unique nor surprising. In fact, it is an international phenomenon, as it is a problem that spans the globe in the form of out-of-field teaching. Qualified teachers from North America to Africa, Australia, India, and Korea find themselves under qualified or unqualified for their classroom teaching assignments as they are assigned to teach courses for which they have little or no background (Hobbs, 2013; Ingersoll, 2003). In previous research, Ingersoll found the high levels of out-of-field teaching are the leading source of under qualified teaching in schools across the nation (Ingersoll, 1999, 2002). The reasons for this phenomenon are many. 
The problem of out-of-field teaching stems from many causes, one such cause is the difference between pay scales of affluent and low-poverty school districts. There is also a marked difference in student achievement between high and low poverty schools with large minority populations (Haycock, 2002, 2003). According to Haycock, there is also a culture within the education profession in which a teacher's status flows from the elite backgrounds of the students they teach, rather than from their own effectiveness. Tenured, more experienced teachers choose to work in schools with higher achieving students and fewer discipline problems. Seniority related transfer policies and practices allow the best teachers to teach in the best schools (Haycock, 2002, 2003 Ingersoll, 2001).

These practices often leave the most disadvantaged students with the most unqualified teachers. Poor and minority students are more likely to be taught by uncertified, under qualified teachers. Both Haycock, Ingersoll and Darling-Hammond, contend that 30 percent of core academic courses in high poverty secondary schools are taught by teachers who lack certification in the courses they teach. This is in stark contrast to just 17 percent in low poverty secondary schools. (Darling-Hammond, 2001, Haycock, 2003 and Ingersoll, 2002). At the same time, 28 percent of core area teachers in high-minority schools do not have appropriate certifications, compared to only 19 percent in schools with low minority populations (Ingersoll, 2002).

One in three secondary core academic classes in high-poverty schools is taught by teachers with neither and minor or a major in the subject. The same holds true for students in high minority schools. In schools that are more than 90 percent AfricanAmerican, 35 percent are taught by underqualified teachers (Ingersoll, 2002, Haycock, 
$2002,2003)$. These practices often leave the most disadvantaged students with the most unqualified teachers. Poor and minority students are more likely to be taught by uncertified, under qualified teachers. Both Haycock, Ingersoll and Darling-Hammond, contend that 30 percent of core academic courses in high poverty secondary schools are taught by teachers who lack certification in the courses they teach. This is in stark contrast to just 17 percent in low poverty secondary schools. (Darling-Hammond, 2001, Haycock, K., 2003 and Ingersoll, 2002). At the same time, 28 percent of core area teachers in high-minority schools do not have appropriate certifications, compared to only 19 percent in schools with low minority populations (Ingersoll, 2002). These authors agree that this practice has a negative influence on teachers' ability to produce high levels of student learning.

Title I of Elementary and Secondary Education Act (ESEA) addresses the goal of enhancing academic achievement for disadvantaged children. With regards to teachers, Title I requires that states prepare and disseminate a report to stakeholders on the quality of teachers and the percentage of teachers being taught by highly qualified teachers, those teachers possessing a bachelor's degree and is licensed to teach and fully certified upon passing a state licensure exam (Whitehurst, 2002, dese.mo.gov.2016). It also requires that states disclose classes which are not taught by qualified teachers. A goal of the bill is to ensure that students in less affluent areas have access to highly qualified educators.

\section{School Budgets and Funding for Teacher Training}

While specific budget lines and items vary district-to-district and state-to-state, two broad general categories that apply to most schools are instruction and curriculum and staff development. Instruction ensures that students have a qualified teacher, 
teachers have instructional aides, and classrooms have needed supplies Curriculum and staff development budgets provide for curriculum, training and instructional support to ensure teachers are able to provide students with necessary knowledge and skills (Ellerson, 2012).

Some authors agree that due to budget restrictions, school districts are often unable to fund extensive training for new and out-of-field teachers (Jacob, 2007, Brown, 2008, Ellerson, 2012). They also contend that late budgetary constraints contribute to the problem in that staffing decisions are often made late, after granting well-qualified, tenured teachers the choice to transfer to schools with higher student achievement levels. Thus leaving un/under-qualified teachers to teach low-income minority students, who need qualified, experienced teachers the most (Darling-Hammond, 2001). Building level administrators are charged with the problematic task of staffing schools while operating under tight budget constraints. Filling teacher vacancies can cost up to $\$ 10,000$ in real money and staff time for each vacancy (Brown, 2008). This costly expense of time and effort can be burdensome to high-poverty schools whose vacancies are hard to fill (Ingersoll, 2002).

Although teacher training is subject to an elaborate array of licensing requirements, once hired, there are far fewer regulations as to how teachers may be used. Thus principals find hiring teachers to teach outside their fields is less expensive and more efficient than hiring more qualified teachers (Ingersoll, 2002). Ingersoll cites the example of a principal who rather than find and hire a new science teacher to fill a statemandated, but under-funded science program assigns English and social studies teachers to cover a few sections of science (Ingersoll, R.,2002). Principals may also choose to hire 
less qualified candidates who are willing to perform extra-curricular duties, such as coaching. Still another alternative is to leave hard-to-fill vacancies open and shift student enrollment to existing classes. While this practice creates larger classes, it also saves salary costs and reduce the number of out of field teachers (Ingersoll, 2002).

Prevalent across all literature was the need for professional development and effective alternative teacher training programs. Several authors suggest the Federal funds be redirected and earmarked for such training, particularly in the case of mid-career teachers who eager to teach and are potentially quality teachers. The authors argue that if given support and training these individuals will remain in the field and find success (Darling-Hammond, 2001, Ingersoll, 2002, Ingersoll, 2003, Brown, 2008).

Over the past decade, federal and state policies and initiatives have focused on two general approaches to ensuring that qualified teachers staff every classroom: upgrading the qualifications of teachers and increasing the number of teachers supplied. Prior to the late 1990s, programs such as the Eisenhower Professional Development Program provide for in-service training and professional development support for effective teaching practices in the areas of reading, mathematics, and science (Ingersoll, 2003). A shift in the focus of the $105^{\text {th }}$ Congress aimed its legislative work at pre-service training and teacher recruitment. In addition to the $105^{\text {th }}$ congressional focus, the Higher Education Funding Act provided funds for statewide initiatives to improve teacher quality by improving higher education's teacher preparation programs, as well efforts to support teacher recruitment to reduce shortages in high-need schools (Ingersoll, 2003). In 2000 , the $106^{\text {th }}$ congress continued the federal emphasis on improving teacher quality by stipulating how funds from the Eisenhower Grant were to be utilized. School districts 
often characterize professional development as programming and thus typically underestimate other investments in teachers' knowledge and skill, such as monies on salaries during in-service workshops.

Congress specified that Eisenhower funding could be used for mentoring new teachers, professional development to retaining effective educators, and teacher recruitment of mid- career professionals in non-teaching occupations. This allocation of funding set the perimeter for ensuring that the nation's students were taught by a highlyqualified teacher who held a bachelor's degree, a state-approved teaching certificate and competence in the academic subjects taught by the individual.

However, allocation of funds is only part of the problem, according to Stephen Sawchuck, researchers have discovered that school districts rarely have a good handle on how much they are actually spending on teacher training and what the spending actually buys in teacher and student learning (Sawchuck, 2010).

While Title I of the Elementary and Secondary Education Act (ESEA) focuses on placing high-quality teachers in the classroom by mandating preservice credentials, Title II approaches the same goal through the funding of in-service professional development for teachers. Whitehurst explains that many forms and functions of professional development are allowed under Title II. One focus is to increase teachers' knowledge of the academic subjects they teach through intensive, classroom-focused training. Title II also focuses on obtaining alignment between professional development activities and student achievement, state assessments, and state and local curricula (2002). 
A firm knowledge of academic subject remains a teacher's best tool in the classroom. "The effects of teacher training on academic achievement become clearer when the focus becomes subject matter knowledge as opposed to certification per se"(Whitehurst, 2002. p.45). The author goes on to say that research indicated that high school math and science teachers with a major in their field have higher achieving students than out-of-field teachers. In advanced math and science courses in which content knowledge is more critical, the effects on student achievement were even greater (2002). The 2000 National Assessment of Educational Progress found no relationship between math scores at the fourth-grade level and teacher's major. In his 2002 study on teacher effects on student achievement, Rowan also found that the teacher's major and level of education and content certification had little effect on student achievement at the elementary level. (Whitehurst, 2002, Rowan, B., 2002). These findings suggest that strong content knowledge has a greater impact on student achievement at the secondary level than it does at the elementary level. Rowan further proposes that subject matter knowledge as currently transmitted to pre-service by colleges of education is not useful in the elementary school classroom (Whitehurst, 2002). Although many school districts provide incentives for teachers obtaining advanced degrees, this does not fully address the needs of teachers from state to state and district to district. The authors contend that the more time teachers spent in targeted training on framework and curriculum, the more their classroom practices changed in ways that were consistent with content reform, and they more they learned about content standards for that reform (Whitehurst, 2002, Archibald \& et al., 2011). 
Unfortunately, too many professional learning activities are not connected to teachers' actual practice and school improvement goals and are not designed to meet the needs of adult learners (Croft, Coggshall, Dolan, \& Powers, 2010). Shifting professional development resources away from one-day workshops and toward intensive, content-rich professional and growth opportunities improve teacher effectiveness and morale (Jerald, \& Ingersoll, 2002).

"Teachers must have ongoing access to technical skills, complex knowledge, sophisticated tools, and research-based techniques to ensure that they are - and continue to be-successful with all students" (Archibald, Coggshall, Craft \& Goe, 2011. p 1.). Highly qualified professional development emphasizes the importance of more intense, content-focused learning activities as opposed to one-day generic workshops. It also provides opportunities for peer collaboration and more structured induction experiences for new teachers (Whitehurst, 2002). Teachers who participated in focused training and whose classroom practices moved toward incorporating frameworks of new initiatives and curriculum of focused professional development saw greater success in test scores imported by the context of their curriculum (Whitehurst, 2002). Whitehurst suggests that when professional development is focused on academic content and curriculum that is aligned with standards-based reform, teaching practice and student achievement are likely to improve (2002).

\section{Struggle to Find Qualified Staff}

Many school districts in the U. S. find it difficult to obtain qualified applicants to fill teacher vacancies as birth rates increase, immigration flourishes, class sizes decrease and the retirement rate surges (Brown, 2008). The fact that subject areas such as math, 
science, foreign language and special education classes persistently remain hard to fill at especially high rates in high-poverty student populations, compound the problem of school staffing (Brown, K., 2008, Haycock, K., 1998, Ingersoll, 2002, Jacob,B.,2008).

To address the problem of teacher shortages, many states have developed strategies to attract and recruit new teachers. These strategies include alternative certification pathways, which target minorities and mid-career professionals from nonteaching occupations (Ingersoll, 2003). Other strategies have included removing barriers and easing requirements for granting reciprocity to teachers certified in other states, recruiting future teachers at high schools, and programs that make pension programs beneficial to retired teachers who return to the field. Other incentives offer partnerships between teacher education programs and school districts (Ingersoll, 2003, Berry, 2001). Some states offer financial incentives for teachers of science and math in high need schools.

States often use compensation as a strategy for recruiting and retaining quality teachers through signing bonuses, student loan forgiveness, tuition reimbursement, as well as housing assistance (Ingersoll, 2003). Increased salaries and merit pay for existing teachers have been used to retain highly qualified educators, in hopes of discouraging them from transferring to more affluent districts which may offer better salaries for comparable experience (Darling-Hammond, 2001, Ingersoll, 2003, Brown, 2008). Still, a more common approach for many states has been offering incentives for National Board Certification. $68 \%$ of states offered financial incentives, while $54 \%$ offered incentives related to certification (Ingersoll, 2003, Education Week, 2000). 
To improve the quality of education in urban schools, districts also focus on school leaders. JoAnne Bartoletti, Executive Director of the NASSP (National Association of Secondary School Principals) and Gail Connelly, Executive Director of the NAESP (National Association of Elementary School Principals), assert that great schools do not exist outside of great leaders (NAASP, 2013). School districts must concentrate on appointing effective school leaders who will work with teachers to develop a climate that supports instructional improvement and values effective teachers (Jerald \& Ingersoll, 2002). The job of the principal is at the least, multifaceted. School leaders need to be educational visionaries; instructional and curriculum leaders; assessment experts and disciplinarians while creating a learning community that fosters positive public relations with all stakeholders. At the same time they must function as budget analysts; facility managers; special program administrators; and expert overseers of legal, contractual, and policy mandates and initiatives (NASSP, 2013)

There are virtually no documentation of troubled schools being turned around without the power of an effective leader. Of the many factors that contribute to such turnarounds, leadership is the catalyst (Leithwood, Seashore-Louis, Anderson and Wahlstrom, 2004).In an effort to attract and keep the right leaders, particularly in lowperforming schools, states and districts should draw on the following effective but underutilized approaches to preparing them for the job (Wallace Foundation 2017): Provide better and more selective training to prepare transformative leaders whose goal is to turn around failing schools by significantly improve teaching and learning. 


\section{Teacher Turnover}

Ingersoll (2003/2011) warns that educators are leaving the field at alarming rates. "Teacher attrition rates in the United States are high, with almost $40 \%$ of new teachers leaving the field within their first five years in the profession." Ingersoll goes on to say, "Certainly all professions have turnover, and some shuffling out the door may be good for bringing in young blood and fresh faces, turnover in teaching is about four percent higher than other professions." (Ingersoll, 2003 in 2013, p2). Ingersoll himself left the classroom after only six years of teaching social studies and algebra in both public and private schools. He then pursued a Ph.D. in sociology and is now a professor in the University of Pennsylvania's education school. He has spent his career searching for answers to the problem of teacher turnover (Riggs, L., 2013).

“One of the biggest reasons I quit was sort of intangible," (Riggs, L., 2013, p.2) says Ingersoll of his departure from the classroom. "But it's very real: It's just a lack of respect," he says. "Teachers in schools do not call the shots. They have very little say. They're told what to do; it's a very disempowered line of work," (Riggs, L. 2013, p2). Ingersoll is not alone, other educators echo his sentiment and add that stress and worklife balance coupled with overwhelming amounts of after-hours work, influenced their decision to leave the classroom. (Riggs, L., 2013; Wynn, et al. 2007) Thomas Smith, a professor at Vanderbilt University's education school, states that what teachers are asked to do is something that one can do for only two or three years. He contends that one cannot maintain that level of intensity throughout an entire career (Riggs, 2013). Yet stress is only one reason that many leave the profession after only a few years of service. 
Overcrowded classrooms, outdated textbooks, and a lack of resources in urban schools influence a teacher's ability to be successful. For these reasons many teachers leave impoverished districts to work for more affluent, less challenging ones (Brown, 2008; Peske \& Haycock, 2006). In one study, S.M. Johnson (2004) found that all teachers sampled who moved from one school to another did so to transfer to a school serving a wealthier student population. This leaves minority populations of poor, non-White, low performing students with the least qualified and or skilled teachers, and according to Lankford, Loeb, and Wyckoff, (2002) makes it difficult to staff urban, high schools with experienced and qualified teachers. Brown and others also contend that teacher autonomy, collegial atmosphere, administrative support, higher pupil expenditures, fewer office discipline referrals (ODR) and increased professional support staff were key factors in teacher retention (Brown,2008). An Education Trust study found that school districts with competent principal leadership, smaller class sizes and better pay and benefits, along with other collegial support make it easier to fill positions in impoverished schools with qualified teachers (Futernick, 2010).

According to Sammons et al., 2007, as cited by Yonezawa et al., (2011) those who study teacher resiliency believe it is often tied to a mixture of individual characteristics and environmental supports and how teachers approach the common challenges of underprivileged schools and districts is key to understanding teacher resiliency. Leaders in some districts have been able to dramatically reduce teacher attrition by improving the teaching environment (Futernick, 2010). 


\section{Conclusion}

Ample evidence supports that students from all demographics perform better with qualified, experienced teachers (Darling-Hammond, 2006). Teachers need the highest quality professional development that incorporates the structural realities of schools in light of inequalities in teacher distribution and student achievement (Yonezawa, S.,

Jones, M., \& Robb-Singer, 2011). This need is especially great in urban schools with underqualified teachers (Ingersoll, 2002, Futernick, 2010). 


\section{Chapter 3}

\section{Methodology}

\section{Research Design}

The focus of this study seeks to understand how out-of-field teacher involvement in professional development impede or promote quality teaching participation and engagement with the district's professional learning practices. Through the use of teacher interviews, information will be gathered based on teacher perceptions of the mentor and teacher induction programs as well as professional development and its perceived impact on teacher success.

A qualitative research design was chosen for this study as it is a means for exploring and understanding how individuals or groups make sense of the human condition or a social problem (Creswell, J., 2009; Seidman, I., 2006). Creswell notes that meanings are constructed as individuals engage in the world they are interpreting, based on their historical and social perspectives. This study will focus on the individual meaning that teachers derive from the complexity of their professional development participation. Using a constructivist lens to view as much as possible how individuals seek understanding of the world in which they work, the participants, took part in interviews both individually and as part of focus groups (Creswell, 2009). Teachers examine and explain their perceptions of professional development and their role in the success of teacher support systems.

Research questions below seek to understand and explain the perceptions of outof-field teachers as to their role in the success of professional development programs. Additionally, answers to these questions will provide insight into the teachers' 
perceptions of professional development and the support they receive in enhancing their content knowledge and their effectiveness as teachers.

\section{Research Questions}

1. How do urban, out-of-field teachers and mentors perceive the quality of their school districts' professional development efforts?

2. How do urban out-of-field teachers and mentors contribute to the sustainability of professional development in their schools?

3. How do urban, out-of-field teachers and mentors understand their contribution to the sustainability of teacher developmental support systems in their school?

\section{Research Sample and Participant Selection}

Two categories of teachers participated in this study the first were first and second year-teachers, enrolled in beginning teacher mentor and induction programs designed by the state of Missouri and their school districts. These mentee teachers possess an Initial PC (Professional Certificate) classification, which is a four-year license, requiring two years of mentoring, annual evaluation and participation in a beginning teacher assistance program. They must also develop a plan for professional development and complete a total of 30 hours of contracted professional development over a four-year period (dese.mo.gov.2016). The teachers who participated in this study are out-of-field teachers. There is also a veteran teacher among the participants who is also an out-of-field teacher. These teachers are assigned by school administrators to teach subjects for which they are not certified or under qualified as these subjects do not match their certification or training (Ingersoll, 2002, Hobbs, 2013). The second group of teachers serve as mentors to the first and second-year teachers. 
Mentors are critical to the development of out-of-field teachers, as mentors are assigned to help new teachers. They assist the teacher in survival, as he or she becomes acclimated to the building and the district. Mentoring is not sustained professional learning which helps a teacher develop expertise in his or her craft. It is, however, support for teachers in their first year of teaching. There are two types of mentoring support. The first, psychological support addresses pressing personal and emotional needs, while instruction related support provides teachers with skills to tackle the more basic challenges of instruction. A mentor is a valuable component of the induction process, however, mentoring is not induction (Wynn, Carboni, \& Patall, 2007, Wong, 2004). Mentoring is a part of the induction process, aligned to the district's mission, vision and structure in order to be effective. Mentors must be used in combination with the other components of the induction process and trained to the mission and goals of the district (Wong, 2004). Both the mentors and the first and second year out-of-field teachers work in urban school settings in Missouri.

The National Center for Education Statistics (1996), Lankford, Loeb and Wycoff (2002), authors of Teacher Sorting and the Plight of Urban Schools, and Pat Russo (2004), the Coordinator of the Center for Urban Schools all categorize urban schools as: schools located in an urban area which is not rural, small town or suburban. They are categorized as high need schools with relatively high rates of poverty, measured by their free and reduced lunch data, as well as their high proportion of minority students. Urban schools may also consist of a large number of English as a second language learners (ESL). The urban setting from which these participants were chosen meets all of the aforementioned criteria, with the exception of that of a high proportion of ESL learners. 
This study will include focus group interviews from three out-of-field teachers, two of which are new to the profession and participating in teacher induction programs, and all of which are teaching out-of-field. The teachers selected were chosen from a survey of middle school educators from an urban setting, who are teaching out of their field. The interviews will be semi-structured, giving the participants the opportunity to freely talk about their experiences as well as answer direct questions (Creswell, 2007). All participants will be interviewed at a neutral site such as public library, outside of their school setting to ensure that they are in a non-school or district setting and able to speak freely.

\section{Phenomenological Approach}

A phenomenological study describes the meaning individuals ascribe to their lived experiences of a concept (Creswell, 2007). The lack of under-qualified and or outof-field teaching has created a perceived shortage of teachers in large, urban areas with large minority populations (Berry, 2004, Darling and Hammond, 2001, Jacob, 2007, Lankford, et al., 2002). This recognizes the phenomenon of professional development experiences through the stories of out-of-field teachers (and mentors) in hard to staff schools. The phenomenological qualitative method was used in the study. Qualitative research allowed the researcher to seek answers to questions that applied to human and whole experiences. The design of the study aligned to the model credited to Moustakas (1994). The pre-reflected ideology throughout the study was to acquire knowledge by investigating descriptions that led to the essence of connected experiences.

Contextual information from out-of-field teachers (and mentors), and how they perceive quality support systems in their schools and their role in the success of those 
support systems will be gathered through interviews and participant journals. The researcher will gather information as to how the participants perceive quality support systems and the meaning they derive from their experiences. Because interviews provide a way for individuals to make meaning of their experiences and tell their stories, the interview will be used to understand the lived experiences and the meanings they make of those experiences (Seidman, 2006). This data will consist in-depth interviews as well as information from participant journals (Creswell, 2007). As it is important to understand the common or shared experiences of teachers as they perceive support systems.

Transcendental phenomenology describes research as focused on the descriptions of lived experiences of participants and their interpretation of those experiences (Creswell, 2007, Seidman, 2006). Researchers set aside (brackets) their own experiences to take a fresh perspective as they view the experiences of the participants. The procedure for this research consists of identifying a phenomenon for study, setting aside (bracketing) the researcher's own experiences and collecting data from several participants who have experienced the phenomenon. The data is then analyzed and categorized by themes. The researcher develops a textual description of what the participant experienced, a structural description of their experiences, of how they experienced it in terms of the conditions, situations or context, and a combination of the textural and structural descriptions to convey and overall essence of the experience (Creswell, 2007; Merriam, 2009).

In this study, the researcher uses psychologist Moustakas's (1994) approach as it has systematic steps in the data analysis procedure, as well as guidelines for assembling the textural and structural descriptions of participant's experiences. Because it is 
important to understand the common work and training experiences of several participants, a phenomenological approach is best suited for this research. The researcher will bracket out her own experiences and interpretations and focus on the experiences of the participants and their interpretations. The researcher collects the data from participant interviews, individual and focus group, as well as participant journals (Creswell, 2007, Seidman, 2006).

Participants are asked two broad questions: What have you experienced in terms of the phenomenon? What context or situations have influenced or affected your experiences of the phenomenon? These questions focus the attention on gathering data that will lead to textual and structural description of the experiences and provide a common understanding of the experiences of the participants (Creswell, 2007). Other open-ended questions will be asked to define each participant's experiences as related to the phenomenon.

Once the data is collected the researcher analyzes the data, highlighting significant statements that provide an understanding of how participants experienced the phenomenon. Building on the data from the two broad questions, data analysts will sort through the data from interviews and participant journals and highlight significant statements or quotes that provide an understanding of how the participants interpret meaning from their experiences. The researcher categorizes the information derived from the experiences into common themes and poses some theories and generalizations based on the information gathered from participant experiences and literature (Creswell, 2007).

Figure outlines the design of this study. It is an inductive process of building from the data to broad themes to a generalized theory. The chart in Figure 1 was taken 
from John Creswell's $2^{\text {nd }}$ edition, 2007 publication, Qualitative Inquiry and Research Design. The chart outlines the research and interview process in which the researcher gathers information from participant experiences through interviews. The researcher will outline the data, identify common themes and shared perceptions. Looking for broad generalizations and theories based on the information gathered from the participant experiences, the researcher will use the information gathered to record support mechanisms afforded to and used by out-of-field teachers to determine a range of support mechanisms that teachers can draw on in their learning. The inductive logic approach used will assist in identifying what support is provided, what support participants sought and how resources are constructed (Hobbs, 2013). 
Figure 1

\section{Inductive Logic Approach}

The researcher poses some

generalizations and theories based on

the information gathered from

participant experiences and

literature.

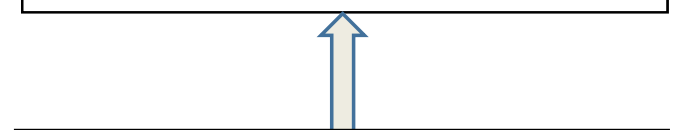

The researcher looks for broad

generalizations or places where

information is overly simplified or

abstruse

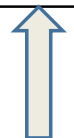

The researcher analyzes the data, outlining common themes and shared perceptions.

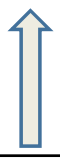

Researcher gathers information from individual interviews, focus groups.

Researcher asks open-ended questions of participants. 
Information gathered during research from interviews will be analyzed and charted in Table 1, (Hobbs, 2013) using three common threads: support provided, support sought, and constructed resources.

Table 1

Support mechanisms used by out-of-field teachers

\section{SUPPORT PROVISION $\quad$ SOUGHT SUPPORT}

1. Support Materials

- Supplies for implementing strategies

- Text resources for teachers

- Assigned reading materials

2.Processes and people

- Mentors

- Curriculum Coaches (District)

- Building level

Administrators

- Teaching Coaches

- Colleagues
3. Professional

Development

- Building level Professional development

- Modeled Strategies

\section{CONSTRUCTED RESOURCES}

6. Personal experiences

- Trial and Error

- Observation of colleagues
4.Collegial sharing and discourse

- Book talks

- Best practices

- Collaborative planning

5. External support

- Professional development sought and paid for by participant
7. Personal research

- Teaching Strategies posted on internet sites by other educators

- YouTube

- Pinterest

- Prezi presentations 


\section{Conclusion}

A qualitative research design is used to examine the support practices of professional development as well as mentoring and induction program opportunities for out-of-field teachers of an urban Missouri school district under pressure from the State to improve student achievement and raise standardized test scores. This study seeks to analyze teacher perceptions of those practices and programs and their sustainability as perceived by teachers. Through the use of focus groups, and teacher interviews out-offield teachers will share their perspectives as to how these teachers perceive the quality of their school districts' professional development efforts and how teacher buy-in contributes to the sustainability of teacher quality support systems. In addition, this study will examine how teachers understand their role in and contribution to the sustainability of teacher support systems designed to make them more effective educators and improve instruction. 


\section{Chapter 4: \\ Research Findings}

The practice of teaching out-of-field can be especially challenging to first and second year teachers who are yet participating in mentor and induction programs. Because professional learning is a lifelong process which delivers growth and professionalism to teachers through an organized, sustained professional development system (Wong, 2004), it is imperative that new teachers receive extensive training and support, if they are going to experience success, especially in the out-of-field classroom.

The phenomenon of out-of-field teaching arises for several reasons, such as, poor school leadership and management, teacher choice, unmet teacher demand and alternative curricula in which teachers teach in cross-disciplinary teams. Ingersoll (Ingersoll, R., 2002) places at the heart of the issue "the manner in which schools are organized and teachers are employed and utilized” (p. 24) In contrast, U. S. schools target supply and demand imbalances and inadequate initial teacher education, Ingersoll contends that policy-makers must improve the quality of out-of-field teachers and increase teacher readiness of teacher graduates $(2002)$.

If the aim is to improve teacher quality, then attending to the professional learning of out-of-field teachers is paramount. At both the school and the policy levels, there needs to be greater support for the retraining of out-of-field teachers so that they can be given the funding, time and space to understand new and emerging teaching approaches. At the school level, conversations can be had with the teacher about subject allocation and the degree of support available and required. 
If the aim is to ensure that teacher candidates are adequately prepared for the reality of teaching, then some responsibility falls on teacher education programs to prepare adaptable and flexible educators. Pre-service teachers must be pre-warned of the likelihood of teaching out-of-field, as well as of the skills, knowledge, and attitudes needed to be adaptable and flexible. They must also be aware of the variety of support mechanisms that can be sought out or constructed by them.

\section{Purpose}

The purpose of this qualitative study was to give a descriptive account of teacher perceptions and perspectives of the professional development and support systems they receive to prepare them for out-of-field teaching. Three elements were cited that could transform teacher quality support systems. The elements under investigation were teacher reflection, the effectiveness of training, and availability of teacher support systems (Ingersoll, 2002). Interviews with the researcher and five professional educators (two tenured mentor teachers, and three out-of-field teachers, two of whom were first and second-year educators) were used to address and answer three research questions. The research questions were formed to examine real-life events that addressed the experiences and perspectives of the participants (Moustakas, 1994). The following research questions were noted in the study: 
Questions for out-of-field teachers and mentors:

1. How do urban, out-of-field teachers and mentors perceive the quality of their school districts' professional development efforts?

2. How do urban out-of-field teachers and mentors contribute to the sustainability of professional development in their schools?

3. How do urban, out-of-field teachers and mentors understand their contribution to the sustainability of teacher developmental support systems in their school? The acquired data, which resulted from the interview process, was analyzed to seek the essence of phenomena (Moustakas, 1994). Chapter four was organized into four sections. The sections are a description of the sample, research methodology and analysis, summary of the findings and the chapter summary. The identification of sources of error and their impact was not found in the methodology or analysis of data within the phenomenological study.

\section{Description of the Sample}

The study sampling consisted of teachers assigned to teach outside of their field of expertise. A second sample included tenured teachers who serve as mentors to first and second-year teachers who are participating in the teacher induction and mentoring processes. These teachers were assigned by their school administrator to teach remedial reading, daily to middle school students, despite the fact that they were not certified or trained in the teaching of reading (Riggs, 2013, Ingersoll, 2002). 


\section{Relative Population Information}

Lakeside Middle School (LMS), the pseudonym used for this study, represented the boundary for samples drawn for this study. The descriptions consisted of being labeled a low performing and struggling school culture. The teaching staff at LMS consisted of approximately $48 \%$ teachers of European-American backgrounds and $51 \%$ percent of African-American descent, while the student population was greater than $98 \%$ African American. The demographics range from low-income to low-middle income households, $96 \%$ of students receiving free or reduced lunch. The school is located within a high-crime community. Student referrals, according to district data, were high due to poor school attendance, fighting, sexual misconduct, cyber-bullying, insubordination to staff and classroom disruptions. The LMS culture was additionally experiencing inconsistencies in school climate due to a large amount of teacher turnover during the previous five years.

\section{Participants and Sampling Methods}

Participants in the phenomenological study were selected based on purposeful sampling (Creswell, 2009). Five teachers were invited to participate in the study. Two were first or second-year teachers, participating in the mentor and teacher induction processes. One was a veteran teacher. The remaining two served as mentors to first and second-year teachers. Four of the five were assigned to teach classes for which they were not certified. The size of the sample population within the phenomenological study was not as vital as the in-depth conversations acquired during the lengthy interview process (Moustakas, 1994). 
Prior to the study, agreements were made with research participants. The agreements cited involvement in a descriptive phenomenology; awareness to disclose information on the topic, and the consent of being taped (audio) recorded. Documents required by IRB and additional documents required by the researcher were read, signed and returned in a timely manner. The participants were given opportunities to ask questions, make comments, or withdraw from the study prior to or during the interview process. A conscious effort was made by the researcher to make the setting as friendly as possible to relieve any possible tension indicated by the participants. The participants were observed as being comfortable in demeanor and social in terms of verbalizing events that pertained to the phenomenon under investigation (Giorgi, 2009).

The five participants were individually interviewed during a scheduled 60 to 90 minute session. The initial interview consisted of the three research questions that addressed their role as out-of-field teachers and or mentors and 15-18 questions that came about during the course of the interview. A thirty-minute follow-up interview was scheduled on an as-needed basis for the purposes of gaining clarity, additional information, or for the confirmation of responses. The initial interview consisted of 18-19 questions that addressed their role as out-of-field teachers and or mentors and their perceptions of the training and development they received to ensure they were effective.

The participants were asked to complete and return demographic information to the researcher. The data was needed to obtain additional participant information prior to the interview process. The documents requested degree information, teacher certification(s), as well as years of teaching experience. The information was provided by the participants and returned in a timely manner. The overall age range of the 
participants was from 28-56. Two participants were of European-American descent, and the remaining three were African-American. The years of experience ranged from 1 to 22 years. Participants either held multiple degrees or were in the process of completing a second degree. The culmination of teaching experiences and background information provided rich conversations throughout the interview process (Moustakas, 1994, Creswell, 2009). The following tables categorized demographic information. One teacher who served as a mentor to out-of-field teachers was excluded from the survey as she was fully certified in the content area in which she was assigned. She participated in the study because she mentored an out-of-field teacher. 
Table 2. Degree Status

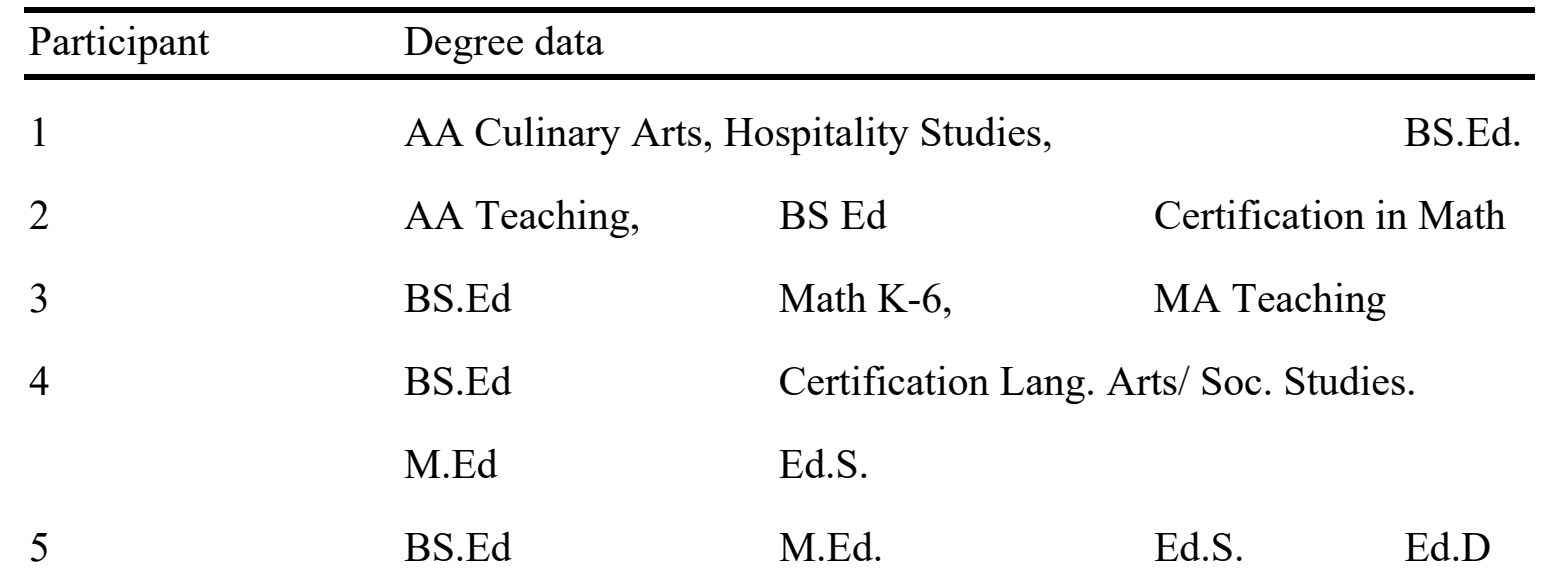

Table 3. Years of Teaching Experience

\begin{tabular}{ll}
\hline Participant & Years of Teaching Experience \\
\hline 1 & 1 year \\
2 & 2 years \\
3 & 20 years \\
4 & 15 years \\
5 & 23 years
\end{tabular}

Table 4. Out-of-Field Roles/Experiences

\begin{tabular}{ll}
\hline Participant & Roles/Experiences \\
\hline 1 & Math teacher, out-of-field teacher of remedial reading \\
2 & Math teacher, out-of-field teacher of remedial reading \\
3 & K- $6^{\text {th }}$ grade Math teacher, out-of-field, under-qualified teacher of \\
& $7^{\text {th }}$ grade math \\
5 & English Language Arts teacher, mentor \\
5 & Science teacher, mentor, out-of-field teacher of remedial reading
\end{tabular}




\section{Research Methodology and Analysis}

The phenomenological qualitative method was used in the study. Qualitative research allowed the researcher to seek answers to questions that applied to human and whole experiences. The design of the study aligned to the model credited to Moustakas (1994). The pre-reflected ideology throughout the study was to acquire knowledge by investigating descriptions that led to the essence of the participant's connected experiences (Moustakas, 1994). The participants in the study shared their perceptions of support and professional development for out-of-field teaching experiences throughout the interview process. The researcher was considered the primary instrument (Giorgi, 2009) for the collected data. The data were transcribed, coded, themed, and descriptively analyzed. The dual purpose of the phenomenological method was to answer research questions within the study and to respond to the topic of interest with academic knowledge and a personal understanding (Moustakas, 1994).

\section{Research Method}

The phenomenological method (Moustakas, 1994) allowed the researcher to investigate human experiences that could not be obtained through a quantitative study (Creswell, 2009). Interviewing provides the context of people's behavior and thus provides a way for researchers to understand the meaning of that behavior (Siedman, 2007). Descriptive data acquired through human perspective substantiated the need for searching for the essence of the meaning of daily lived experiences. The intertwining of emotions, ideas, and opinions placed within conscious behaviors and displayed through personal perceptions gave insight into shared relationships and interconnectedness in terms of events through the process of immersion. The rich responses of the participants 
were the result of in-depth conversations about the phenomenon (Creswell, 2007, Seidman, 2006).

It was vital to obtain rich responses from the participants as well as establish social interchange between the researcher and the participants in an effort to seek the meaning of the whole experience (Moustakas, 1994, Giorgi, 2009, Seidman, 2006). An atmosphere of trust, confidentiality, and comfort impacted each participant's role as they reflected on their own experiences. The elaboration of responses by the participants allowed the researcher to be immersed in the whole experience prior to ending the interview. The researcher used probing questions to solicit in-depth questions from the participants when necessary. The interview process was the foundational element of the phenomenological research (Giorgi, 2009, Moustakas, 1994). Because the goal is to understand the meaning people make of their experience, the interview provides a necessary, completely sufficient, avenue of inquiry (Seidman, 2006). It was imperative for the order of questions to be organized and sequenced in terms of addressing the topic within the study. (Moustakas, 1994).

Interviews were obtained through, Dragon Dictation, a computer recorded software application. Participants were informed in terms of how data would be collected. Verbal agreements were made, and signatures were obtained and filed. The participants were assigned numbers for the purpose of identification. Information inclusive of recorded transcripts, folders, and demographic data for the purpose of clarity and rigor were marked boy number headings. The participants were made aware of the pseudonym process and indicated total agreement prior to the interviews. Therefore, the 
process of confidentiality within the study, the rights of the participants, as well as the privacy of information were confirmed.

The transcripts of the computer-generated interviews were read and reread repeatedly in order to immerse the researcher into the essence of the experiences (Giorgi, 2009, Moustakas, 1994) and to allow the researcher to weed out irrelevant information and focus only on what was pertinent to the research. Information was considered irrelevant if it was busy chatter or off topic of discussion. Participants were contacted via telephone, email or directly when there arose a need for clarification or more questioning. The transcripts were coded. Reviewing and coding transcripts as well as the interview process required time and a total of 15-18 hours. The transcripts were reread and reviewed with the participant to gain clarity in instances where responses were inaudible to the computer-generated transcription program, and clarification was needed. This process allowed the researcher to write with accuracy the highest level of verbatim responses (Moustakas, 1994).

Meaningful units of transcript text were identified and selected to prepare for data analysis. The selection was based on the disclosure of the outcome of the phenomenon (Moustakas, 1994). Seeking meanings while investigating perceptions of out-of-field teaching experiences determined the essence of the investigation. Therefore units of meaning were selected which disclosed the outcome of out-of-field teaching in terms of teacher reflection, professional development and support (Ingersoll, 2001, Hobbs, 2013, Moustakas, 1994). In addition, meaningful units were identified in terms of the topic within the study and the research questions posed by the researcher. The units were then coded and divided into themes based on similar perceptions of the participants. 


\section{Data Analysis}

The coding and theming processes (Creswell, 2009) helped to organize data for textual and structural descriptive analysis. Each participant was assigned a number, i.e. P1, P2 etc. The transcriptions were sorted using five colors, then cut into strips and sorted in terms of similar responses. The strips noting similar responses were placed into corresponding folders. The folders were labeled according to the theme and corresponding color. The five emerging themes cited meaningful experiences (Seidman, 2006) of out-of-field teachers in terms of their perceptions of professional development, building and district support systems, and teacher buy-in (Ingersoll, 2002, Darling \& Hammond, 2001, Haycock, 2002, Riggs, 2013). Table 5 aligns the interview protocol question with elements of out-of-field teaching.

Table 5 Interview Questions Listed by Number and Out-of-Field Teaching Experiences

Questions by number

I.B, I.B, I.C, I.E, I.F, II.C, II.4

III.D, III.F

II.B, III.A, III.B, I.D, III.C, III.E, III.B, IID, I.C III.D

II.A, III.E, II.B

\section{Elements}

Ineffective training, professional development, practice

Time

Buy-in

Support

Desire for success

\section{Summary of Findings}

The summary of findings section included the types of descriptions that were analyzed as textual, structural, and textual-structural. Textual descriptions focused on the daily descriptive events of the participants in terms of perceptions. Their perceptions 
gave insight in terms of the awareness and reflection of professional educators as out-offield teachers (Seidman, 2006, Moustakas, 1994). The researcher used references to categorize descriptions. The descriptive references included: frustrated, excited, hopeful, and out of the box. The textual descriptions of the participants were based on phenomenological reductions (Giorgi, 2009, Moustakas, 1994).

Avoiding any bias or prejudice was constantly present throughout the interview process in the mind of the researcher (Seidman, 2006). The researcher was considered the major instrument for collecting data that led to the meanings of lived experiences (Moustakas, 1994, Seidman, 2006). Therefore, the lived experiences of the participants were seen through the lenses of pre-reflective knowledge and insight by the researcher to uncover the essence of the phenomenon throughout the investigation (Giorgio, 2009).

Structural descriptions allowed the researcher to expand findings in terms of polarizations, difficulties, and imaginative variation (Giorgio, 2009, Moustakas, 1994). Imaginative variation allowed the researcher to gain additional insight into the whole experience. It allowed for immersion into the essence of the phenomenon without taking away from the data. The data in the phenomenological study was valuable in the justifying of perceptions of the participants based on conscious and objective experiences (Giorgio, 2009, Seidman, 2006). The researcher's role was to listen and experience references within the text, emerge into the conscious experiences of the participants within the structural description and arrive at the true essence in terms of integration. The researcher gained authority in terms of making sense of the experience and applying possible meanings based on reflection and immersion. The researcher was given power to expose the phenomenon and to interpret the essence of the whole experience through 
the subjective perceptions of all out-of-field teacher participants and their mentors (Giorgi, 2009, Moustakas, 1994).

\section{Themes}

A total of five themes emerged probing perceptions of out of field teachers participating in this study (Moustakas, 1994) as a result of the interview questions. The interview questions were scripted to prompt responses that related to specific topics. The researcher noted, however that individual responses led to free-flowing conversations (Creswell, 2009, Moustakas, 1994). Therefore, responses to the questions would overlap and address more than one topic. Overlapping was noted during the transcription phase. Responses from the participants were often similar and targeted the perceptions of out-offield teachers and mentors, based on reflection, professional development, buy-in and support (Ingersoll, 2002, Darling \& Hammond, 2001, Haycock, 2002, Riggs, 2013).

Table 6 characterized identification and responses and used pseudonyms for quoted responses by participants.

\begin{tabular}{ll}
\hline Pseudonyms & Symbol for Quote \\
\hline Participant 1 & P1Q \\
Participant 2 & P2Q \\
Participant 3 & P3Q \\
Participant 4 & P4Q \\
Participant 5 & P5Q \\
\hline
\end{tabular}


The following themes identified the perceptions of educators based on the daily lived experiences as out-of-field teachers and mentors. (Seidman, 2006, Moustakas, 1994). The themes aligned with questions in the study.

Theme 1: Ineffective training/professional development/practices. "Each year, schools, districts, and federal government spend millions, if not billions of dollars on in-service seminars and other forms of professional development that are fragmented, intellectually superficial, and do not take into account what we know about how teachers learn”(Borko, 2004 p. 13). According to Sykes (1996), the inadequacy of professional development is "the most serious unsolved problem for the policy and practice in American education today" (p.465).

Because it is often difficult to staff urban schools, many teachers are assigned to teach classes which they are not qualified to teach. These teachers teach outside of their field of study or expertise, this makes the need for content area professional development crucial to their success (Ingersoll, 2002, Jacob, 2007). Teachers must have an organized, rigorous, professional development system.

Out-of-field teachers and mentors shared common concerns regarding the effectiveness of professional development. Their reflections on effective and ineffective practices were valuable and gave the researcher insight into their perceptions of the support they did or did not receive. The participants cited the need for the school district to provide intense professional development on a regular basis, as it relates to the curriculum.

P4 shared an observation she made during a building level professional development. 
The training was given during the grade level, professional learning community meeting. This was of immediate concern to the participant because the training session was a little less than an hour long. P4Q stated, "I wondered if there would be ample time to ask questions and troubleshoot potential problems before the meeting ended. There was not."

P4 recalled that the trainer, acknowledged the shortness of time, which the participant felt was already an admission that the training was not going to be beneficial, therefore in her opinion, the trainer was apologizing beforehand. The presenter quickly passed out the materials, read from a PowerPoint, then had the teachers practice the strategy she demonstrated. The teachers were told that they would receive a copy of the PowerPoint and materials to print and use in their classrooms. The presenter answered a few quick questions and left to go to the next grade level meeting. Teachers still had many concerns. P4Q stated, "It would have been helpful if the trainer had modeled the strategies with 7th grade students who were reading at different grade levels, so that we would know what the strategy would look like in the classroom with our students."

P5 agreed and remarked that therein is another problem; differentiation.

P5 noted that differentiation could be challenging to the most qualified of teachers. PQ5 stated, "To add differentiation to the equation created an even greater challenge for teachers who were already struggling with out-of-field content."

Participants unanimously expressed a desire to have input into the types of professional development they receive. P1Q stated, "The district solicits our opinion, but does not take it into consideration. They give us what they think we need." P3Q stated, 
“They have us fill out surveys, but nothing really changes. We still don't get the training that we ask for."

Participants commented on the relevance of the professional development provided. The educators who believed the professional development was relevant, felt it was not practical or useful on a day-to-day basis. P4Q stated, "This forces the teacher to focus on the content/teaching standards, putting the district professional development on the back burner." Participants expressed that the district focused on too many initiatives at once and the focus was too divided. PQ1 stated, "It is difficult to choose where the focus lies when there are so many initiatives: building, district and content. We have to choose where to place the focus: some district initiatives often emphasize changing the climate or building character. Most teachers feel these take away from time that should be spent on academics. We want to focus on the standards and increase skill levels. When you are looking at deficits in skill level, you tend to put your focus on that area. A lot of the character building falls on deaf ears when the value systems of home and school don't necessarily agree. Its challenging enough teaching a subject for which you are not certified, sometimes it's just easier to ignore the other initiatives when you can.” $\mathrm{P} 3 \mathrm{Q}$ agreed, saying, "Most initiatives are not closely monitored, so it's easy to just not follow them."

P2Q stated, "The only follow-up I can recall is when the instructional coaches came to a grade level professional learning community (PLC) meeting and asked to share a reading strategy that we used the previous week from a reading strategies book that was given to us the week prior. It wasn't beneficial at all because there wasn't enough time given to us to read the book, before the upcoming PLC." 
P4Q recalled her experience with district training saying,

For example, the district professional development that has been pushed from year to year has been assessment for learning. While I love what assessment for learning has to offer us, this professional development does not give us what we need. We are at a point where we need to focus on standards, and the knowledge that we are putting into our students brains. Looking at test scores, is easy to see that while this may be a district initiative, it is definitely not an area that our building needs to focus on. So it's like we're stuck between a rock and a hard place.

P4Q went on to say, "For district-wide professional development days, the district does send out surveys asking what kinds of professional development would benefit us most. When we arrive at professional development, the item that we chose may not have even made it to the list. If it did, that one specific room is filled with teachers and packed to capacity."

Teachers interviewed for this study, feel that if professional development is to be effective, it must be consistent and provided on a monthly basis, with follow-up between training sessions. Implementation must be monitored to ensure fidelity of practice Teachers must receive feedback and additional training if necessary. It must also be relevant to the work that is done in the classroom, reaching students at all levels. P5Q addressed the frustrations of the uncertainty of effectiveness, "The professional development I have received is relevant to the work I perform in the classroom, but only to a very small percentage of students." P1 agreed with P5, stating, "The students in my class are on such varying levels, it's hard to address the needs of all the learners. It seems that the building professional development is geared toward the middle-level students. 
I'm not certified in teaching reading, I just don't know how to ensure that I am effectively helping all of the students." Overall, participants experienced frustration with what they perceived as ineffective training. Despite the perceived lack of depth in training, the participants in this study maintained a strong desire for success for themselves and their students.

Theme 2: The desire for success.: When the professional development provided does not meet teacher needs, out-of-field teachers often seek resources and strategies on their own Hobbs, 2013). Information gathered from participants recorded support systems afforded to and used by out-of-field teachers to determine a range of support systems that teachers can draw on in their learning. The inductive logic approach assisted in identifying what support is provided, what support participants sought and how resources are constructed (Hobbs, 2013). Note the comments on finding success on their own made by out-of-field teachers.

Teachers express a desire to be successful and a willingness to seek out success on their own. P1Q stated, "I want to be successful, but I feel I am ill-equipped."

P2Q stated, It's my job to ensure I'm using the things I've learned, but if what I learned isn't anything new I just keep doing what I am do. For instance, in the literacy class they wanted the students to write in a particular format, but my students were already using this format in their English classes. This was nothing new to the students or to me. I felt we could have benefited from learning more about strategies for reading comprehension, since teaching reading is not my expertise. I honestly just do my own research and go from there. In my spare time, I research reading strategies, best practices and talk to 
reading teachers in and outside of my building to see what they are doing. PQ3 also acknowledged a responsibility to implement the professional development saying, "The strategies that I have received from professional development became my responsibility to implement and ask questions if I had difficulty."

P4Q went even further, recalling collective efforts of teachers solving problems:

Do you remember when they gave us the Google Chromebooks? Students at our school, overnight, each were the proud owner of Chromebooks. Each student had a Chromebook. And teachers received no professional development about how to use Chromebooks in the classroom. It took teachers, researching, and sharing information on their lunch break and on their plan time with each other in order for us to learn how to use the computers. It was really a grassroots effort in order to make 21 st Century Learning come alive. The district did not help us accomplish this. We, the teachers, figured out how to use Google classroom, and we figured out how to make meaningful assignments for our students. But that was only on the 7th grade team. I'm not sure what other teams were as lucky as we were.

As a mentor, participant 5 reported assisting mentees in using data regarding students' prior knowledge, needs and interests from school records, diagnostic and standardized test, and from formal and informal classroom assessment of students' progress in planning instructional activities. P5Q stated, "It's important to update one's knowledge of the teaching/learning process, child and adolescent development, emerging technologies, and the general field of education and to incorporate new knowledge into one's practice in an ongoing manner." The participants agreed that sustaining their 
professional development was their responsibility. The district did not always provide them with PD that supported their responsibilities as learners.

Theme 3: Participants role (Buy-in). While enrolled in teacher training programs, many education candidates complained of being placed in low-performing, high-minority schools as part of their certification process. Less affluent school districts are often avoided by experienced, tenured educators. Surprisingly, many teacher candidates sought out and accepted positions in the very communities they once saw as deficient (Leland \& Murtadha, 2011). So therein is the first step in buy-in, the commitment to serve. These educators have proven that they want to ensure, not only their own success but also the success of their students.

It is critical that these individuals receive additional training and support to enhance their knowledge and skill base to increase their effectiveness as educators (Haycock, K., 1998, Ingersoll, 2002). In her research, Haycock found that when taught by effective teachers, low-achieving students gained more than 53 points on state tests. When professional development is focused on academic content and curriculum that is aligned with standards-based reform, teaching practice and student achievement are likely to improve (Whitehurst, 2002). It is imperative that teachers buy into the professional development practices provided by their schools and school districts. Note comments regarding buy-in made by out-of-field teachers and mentors.

Participants expressed an understanding that buy-in was critical to implementing professional development with fidelity. Personal buy-in is the acceptance of and commitment to a specific concept or course of action. Here it is the agreement of people 
agreeing to accept something and provide their support. Their discourse centered on the notion that the professional development they were receiving was not beneficial to the work they were doing. P3Q stated, "The professional development that has been provided by my district has not been beneficial to me or the students. Therefore, it is impossible to buy into something that isn't useful." Other participants echoed this same sentiment regarding the lack of buy-in.

P4Q stated,

It is difficult to buy into the professional development provided by the district because it seems useless. Teachers often wish that professional development would impact something that directly impacts their work in the classroom. Currently it seems as though professional development is comprised of the new catch phrase in education. Professional Learning Communities; Assessment for Learning... we've been having the same professional development for years and honestly teachers aren't using half of what they learn in professional development. It is rendered as useless to classroom teachers.

P2Q took a more reasoned approach,

Buy-in is difficult if it doesn't feel meaningful. It's not specific enough to the needs of those that are out of their comfort zone, teaching a subject we're not comfortable with. I believe professional development can be very beneficial if it is done the right way with specific needs as the focus.

P4Q expressed a go-along-to-get-along approach to her professional development, 
Over the years, I've learned to keep quiet when I don't agree. Disagreeing or commenting too strongly can be seen as non-compliance and cause you to be labeled as a rebel. So, I just go to the training sessions and when I feel it's ineffective, I just keep my mouth shut, grade student work or play on my phone until it is over.

When asked about the types of professional development opportunities offered at the district or building level, $\mathrm{P} 2 \mathrm{Q}$ went on to say that, "We want to be asked about what we need-not just told what to do. The participants in this study expressed a need to be included in the decision-making processes concerning the type of training and professional development they needed. 
Theme 4: Not Enough Time. A mentor is a valuable component of the induction process, however, mentoring is not induction (Wynn, Carboni, \& Patall, 2007, Wong, 2004). Mentoring is a part of the induction process, aligned with the district's mission, vision and structure in order to be effective. The purpose of the induction phase to engender collaboration through shared experiences, practices, tools and language among all colleagues and to treat new teachers as colleagues and cohorts (Wong, 2004).

Wong (2004) states that isolation is a common thread and complaint among new teachers. Many new teachers voice concerns about not being granted time to observe another classroom. These teachers say that they are not given the opportunity to observe other teaching styles, even that of their mentors, and thus are unable to glean from the effective, creative practices of other teaching professionals. Beginning teachers value the opportunity to observe and be observed by others (Wang, Odell \& Schwille, 2008).

Teachers who receive frequent observations and feedback from their mentors are more satisfied with their mentoring and induction programs and feel they experience more success (Luft \& Cox, 2001). The teachers in this study were no different. They voiced the same concern of not having time to meet with and or observe or be observed by their mentors.

Out-of-field teachers expressed a desire to meet and be observed regularly by their mentors. P1Q stated, "If it were possible, I would have loved to have spent a week observing in a seasoned teacher's class who taught the same subject. Since that was not possible, it would have been beneficial to have an experienced, same subject co-teacher to discuss daily the events of each day for about six weeks, then taper off from there." 
Other participants, commented on the inability to observe or be observed by their mentors due to scheduling or availability. P3Q shared these insights to here mentoring experience,

My mentor and I are not even in the same building. We email and speak over the phone. Occasionally we meet after work, but by then we're both tired and our meetings are usually too brief because of other commitments. I usually write down any questions or concerns that I have, and she gives me pointers. But I know it would be more effective if she were in the classroom observing me and vice versa.

Educators agree that it's equally difficult to sit down and talk with district-level coordinators who come to observe their classes. District level curriculum coordinators and coaches sit in their classrooms for 15-20 minutes and make snapshot observations. They may leave a comment or question on the observation form, but there is no time to sit down and discuss what they observed. Therefore, participants felt the observations were not beneficial. "I'd like for the coordinator to stay for the entire class," commented $\mathrm{P} 2 \mathrm{Q}$. "It would be ideal if he could sit with me after class, discuss the lesson and his observations, then offer suggestions or strategies that would increase depth of knowledge for the students and improve teaching for me."

All of the teachers interviewed in this study think the observation of others and shop talk are important learning activities. "Teachers are encouraged to collaborate, but when the teacher and the mentor are teaching out of field, it can be like the blind leading the blind," stated P4Q. 
Theme 5: Support. Bolman \& Deal, et al (2009) assert that organizations must invest in its members through professional development opportunities. Organizations must empower members by providing information and support, grant autonomy and welcome participation in decision making. Finally, organizations must promote diversity and hold leaders responsible (Bolman \& Deal, 2009, Shafritz, Ott \& Jang, 2005, Del Favero, M., 2003). Key to the success of out-of-field teachers is support. School leaders must provide support for if out-of-field teachers are to be successful.

Although some participants received a great amount of support from their mentors, and most reported a good deal of support at the building level, all reported that no support was provided at the district level for out-of-field teachers. P1Q stated, "I believe, or school has given me some strategies that prepare me to teach this subject, but the district has not." These educators reported a break down in support systems as it pertained to professional development for the context they were assigned to teach. P3Q felt that because she was an experienced teacher, it was just expected that she did not need support. P3Q stated, "I was handed a curriculum and told that I would be fine.” Outof-field teachers expressed a need for basal and scripted curriculum for teachers who were teaching outside of their field of expertise.

While teachers expressed an understanding of the lack of funding for professional development, P4Q stated, "I can see how the a la carte model of professional development would be hard for a district to consistently implement, but I think that it's worth it in order for teachers to have the necessary tools that they need to go in their classroom and be an effective teacher." Still, other participants felt incentives such as reimbursement for outside professional development that teachers sought on their own, or 
college credit for professional development. P2Q stated, "If they would provide classes that could count toward a masters in the field of reading. Time is precious and having us work toward something that would be worth our time and provide adequate training in the field would be great." The participants in this study wanted to be assured that their hard work was valued. It was their perception that such incentives, proved that the school district recognized their efforts and demonstrated a commitment to their success.

\section{Conclusion}

The qualitative phenomenology study sought to investigate the perceptions of five professional educators with a secondary, low-income, high minority school setting. The teachers were interviewed using open-ended questions about their experiences as teachers assigned to teach content outside their areas of certification and expertise (Ingersoll, 2002). Themes emerging from the interviews included the effectiveness of training, professional development, and practices, time, buy-in, desire for success and support (Ingersoll, 2002, Leland \& Murtadha, 2011, Riggs, 2013, Wong, 2004). Chapter 4 identified the target population, demographic data, methodology, and data analysis in the form of themes, codes, and tables. The data analysis expounded on narrative themes in the form of comments by the researcher and quotes from the participants. Chapter 5 will use the data analysis to discuss the results as they pertain to the research questions, relate to the results in the literature, study limitations, implications of result and recommendations for further research.

P1Q stated, "The district solicits our opinion, but does not take it into consideration. They give us what they think we need." P3Q stated, "They have us fill out surveys, but nothing really changes. We still don't get the training that we ask for." P1Q 
stated, "They hired us because we are professionals, they should show us the professional courtesy of asking us what we need and then listening when we tell them. It is one thing to sit behind the desk at a district office and make decisions about what should be done in the classroom. It's a whole new ballgame when you are the one in the classroom that is expected to make it happen."

The essence of out-of-field teaching is the perception that they are not heard as learned from Theme I. Further, out-of-field teachers feel a deep understanding of their responsibility to continue their learning beyond district PD programs. The teachers interviewed perceived their commitment to the work they do in the classroom was greater than the district's commitment to providing them with the necessary training they needed to be successful, as learned from Theme 2 . The teachers in this study felt the district prescribed cookie cutter and one size fits all approaches that did not meet the needs of the teachers or the students as was learned from Theme 3. With more time out-of-field teachers believe they could learn from each other through observing classes and professional conversation, as was learned from Theme 4 . The need for support is crucial to the success of out-of-field teachers, as was learned from Theme 5. Out-of-field teachers have a strong sense of their commitment to the students they teach and the community they serve. 


\section{Chapter 5: Research Findings, Conclusions, Recommendations and Overview \\ Purpose}

This qualitative study sought to understand perceptions of out-of-field teachers and how they make meaning of their experiences as teachers who are assigned to teach courses for which they are not certified or are underqualified. Through qualitative questions, the researcher analyzed perspectives of out-of-field educators about their professional development, their efforts to contribute to the sustainability of professional development and their perceived role in the sustainability of quality teacher supports. The research explored the perceptions of the effectiveness of professional development provided at district and building levels. It also explored teacher feelings of responsibility to support and implement professional development strategies. Furthermore the research sought to analyze the perceptions of the role participants of this study felt they had in sustaining teacher developmental support systems in their school.

\section{Findings: Research Question 1:}

\section{How do urban, out-of-field teachers and mentors perceive the quality of their school districts' professional development efforts?}

From the data, it was learned that teachers believe the professional development efforts provided by their schools to be ineffective. The out-of-field teachers interviewed for this study based their beliefs on their perceptions of training, time allotted to implement instructional strategies, as well as support provided by the school district, administrators and mentor teachers.

Teachers indicated that building level professional development, was often too short and there was not enough time to address questions and concerns. The out-of-field 
teachers interviewed for this study believed that these brief training sessions which were often no more than an hour in length, were not extensive enough for them to consider themselves properly trained. "Teachers must be immersed in the subjects they teach, and have the ability to both communicate basic knowledge and to develop advanced thinking and problem-solving skills among their students"(p.916) (Garet, Porter, Desimone, Birman, and Yoon, 2001). They expressed that the training was not specific or detailed enough for teachers who were teaching outside of their area of expertise. The participants felt their school district offered cookie-cutter strategies that did not target a specific curriculum. These strategies, teachers reported did not assist them in learning to become better teachers, particularly when geared toward subjects they were not qualified to teach. Instead of immersion into teaching strategies, these teachers felt they were whisked through thinly-layered strategies that did not meet their needs. The Education Commission of the States (ECS) report identified key areas where resources should be targeted to enhance the quality of teaching and learning. Among those areas identified was a professional development that builds on content knowledge and teaching skills (Geringer, 2003, Haycock, 1998). The participants of this study echoed a desire for the same.

The out-of-field teachers and mentors also expressed a need for more time to observe and be observed by each other. First and second-year teachers expressed not only a need to observe and be observed by mentors, but also by skilled teachers who taught the same subjects to which were assigned. In addition, the participants stated that they needed more time to practice the strategies learned during professional development. 
Adequate time is also needed to implement the strategies with close monitoring to ensure that learned strategies were done properly so that students would receive the most benefit. In addition to professional development and time, the out-of-field teachers interviewed in this study felt that when strategies were closely monitored, by trainers as well as district curriculum and building level administrators, teachers would have the support they need to be successful and have the greatest impact in the classroom.

As mentioned before, mentoring is not sustained professional learning which helps a teacher develop expertise in his or her craft. It is, however, support for teachers in their first year of teaching. There are two types of mentoring support. The first, psychological support addresses are pressing personal and emotional needs, while instruction related support provides teachers with skills to tackle the more basic challenges of instruction. (Wynn, Carboni, \& Patall, 2007, Wong, 2004). Support was indicated as a key factor in teacher success by the out-of-field teachers and mentors interviewed in this study. Participants wanted more thorough observations by district curriculum administrators with helpful feedback to improve instruction. In addition, they indicated a need for more specific training and professional development in the subjects which they were assigned to teach. The teachers interviewed perceived their success to be tied to the support that they were provided by their mentors and their school districts. The difference between a negative and positive out-of-field teaching experience is the level of support teachers receive, as well as the recognition of how difficult it actually is to teach out-of-field (Hobbs, 2015). 


\section{Findings: Research Question 2:}

\section{How do urban out-of-field teachers and mentors contribute to the sustainability of professional development in their schools?}

Out-of-field teachers and mentors interviewed in this study express a deep understanding of the importance of buy-in to the sustainability of professional development. Buy-in impacts the integrity of the support systems. It is crucial to the success of any program. Teachers depend on those systems to be beneficial. When they are not, teachers interviewed say they are reluctant to buy-in. ultimately the participants of this study expressed that without buy-in there is little or no implementation. Therefore it is then uncertain that the professional development training could have been successful. From the study, it is learned teachers feel that professional development can be beneficial when it is focused on meeting the specific needs of students. Furthermore, the teachers in this study expressed that teacher support systems must be thorough, intensive and ongoing targeting specific academic goals (Borko, 2004, Haycock, 1998).

Although the teachers and mentors interviewed in this study felt that buy-in was difficult and the lack thereof was vital to the success of any quality teacher support system, they all expressed a desire to be successful. The participants were so committed to achieving success for themselves and their students they did whatever they deemed necessary to achieve that success. The out-of-field teachers researched strategies on their own, seeking help from colleagues, electronic media, YouTube videos, Prezi presentations and even paying out-of-pocket to attend content area conferences. For the teachers involved in this study, the level of commitment was high, despite the fact they felt the professional development provided them was often ineffective. 


\section{Findings: Research Question 3:}

\section{How do urban, out-of-field teachers and mentors understand their contribution to the sustainability of teacher developmental support systems in their school?}

The out-of-field teachers and mentors interviewed in this study understand their role in the sustainability of teacher development support systems as one of compliance and implementation. The participants understand that before adopting new initiatives, the district has researched best practices and analyzed student data, to assess the needs of its student population. Therefore, the teachers feel it is a part of their contractual obligation to utilize the strategies and training provided in their classrooms. From this study, it was learned that it is a teacher's priority to make sure they are teaching content standards from day-to-day. The participants identified a lack of support as an inhibitor to that implementation. This concern for the lack of professional support among the participants bares out much of the research (Borko, 2014. Hobbs, 2015, Darling-Hammond, 2002, Ingersoll, 1999).

The out-of-field teachers in this study note that while they receive limited support at the building level, they receive little or no support at the district level. The mentors of out-of-field teachers in this study understood their role to support first and second-year teachers, to provide them with resources and strategies to be successful in the classroom. Mentors feel it is their responsibility to set regular meeting and observation times with follow-up for discussions. In addition, mentors must provide timely feedback so that teachers have an opportunity to adjust their practices so that they are most effective.

The teachers and mentors interviewed in this study understand their assignment to content areas to which they are not certified is a decision made by the building principal, 
(Ingersoll, 2002) and therefore perceive their assignments as the principal's autonomy to make decisions for the building. Still the participants see support at the district level as approval of their work in the classroom. They view support on a larger scale (at the district level) as having the ability to be more intense, in-depth capable of assuring that quality training is supported across the district.

\section{Conclusion One}

Teachers and mentors want professional development that is meaningful to the work they do in the classroom. Educators, especially those teaching out-of-field, need training that is intense, focused and content oriented. They require ongoing training and close monitoring of professional development strategies to ensure that those strategies are implemented with fidelity so that students and teachers experience success. Teachers seek to be the experts of all of their content. They want extensive training that focuses on content standards.

Teachers also want professional development that coincides with district curriculum and collaboration of those goals. Teachers feel that professional development and curriculum go hand-in-hand. When professional development is geared toward curriculum, the benefits of student achievement are heightened as the focus is placed on content and skills needed for student success (Haycock, 1998, Darling-Hammond, 2001).

\section{Conclusion Two}

Buy-in is critical to the success of any professional training. The urban out-offield Teachers in this study wanted to have buy-in, they wanted to comply with the goals the district has set for academic achievement. Teachers understood that their teaching 
assignments are often made at the building level based on the needs of the school. Out-offield teachers want to be assured that the district is operating in their best interest. They want to be included in the decision-making as to what professional development they receive. Teachers want to be heard and know that administrators understand that the work they do is valuable and often challenging.

Out-of-field teachers want the training they receive to provide them with skills and strategies to help them learn to be experts at the subjects they are assigned to teach. These teachers are so committed to finding success for themselves and their students that they research strategies and seek professional development on their own to ensure that they are equipped to assist their students in achieving success. Their dedication to student achievement is evidence of their desire to comply with professional development.

\section{Conclusion Three}

Mentors of urban out-of-field teachers understand their contribution to the sustainability of teacher developmental support systems as that of support. The difference between a negative and positive teaching experience is the level of support out-of-field teachers receive, as well as the recognition that teaching out-of-field is quite difficult (Hobbs, 2015). Mentors feel it is their responsibility to provide emotional as well as professional support to new teachers. Through mentoring programs, these mentors seek opportunities to observe and be observed by their mentee teachers. They provide feedback and strategies for achieving the greatest growth in student achievement. Mentors assist new teachers in the acclimation of building culture and professional developmental expectations. The support provided by mentors encourages retention 
among new teachers and provides them with the skills, emotional support and strategies they need to learn to be better teachers of the content they are assigned to teach.

\section{Recommendations for Future Practice}

The data collected from qualitative interviews of five out-of-field teachers and mentors revealed significant findings for the improvement professional development and support systems for out-of-field teachers in urban regions. The data focused on the effectiveness of professional development, teacher and mentor contributions to the sustainability of teacher support systems and how those teachers and mentors perceive their role in sustaining teacher developmental support systems in their school.

1. The experiences shared during interviews with three out-of-field teachers and two mentors indicate a strong need for professional development that aligns with the work that teachers do in the classroom (Haycock, 1998). Teachers require training that is ongoing, focused and that targets are learning standards identified in district curriculum. Ongoing training provides for continuity for teacher and student success. Teachers need time to process and practice strategies provided as well as time to implement them with fidelity in the classroom. Out-of-field teachers need extra training in courses they are assigned to teach that are outside of their field of expertise (Hobbs, 2015). The participants of this study indicated that they needed feedback from observations of their implementation and close monitoring of their implementation efforts.

2. Teachers and mentors indicated a deep understanding of the importance of buy-in in regards to the professional development provided by their districts. Teachers expressed a strong commitment to achieving success for themselves and their 
students. Out of the desire to succeed comes the drive to create their own success when they perceive the professional development provided by the district to be ineffective. Teachers seek help from their colleagues, literature, electronic media such as Prezi presentations, YouTube videos created by other educators and other internet media sources. Teachers feel a sense of responsibility to professional learning, they plan collaboratively with colleagues and seek out best practices. They also take the initiative to enroll in and pay with their own funds for professional development opportunities that the district will not cover.

Out-of-field teachers need extra training assigned courses that are outside of their area of certification. They must have access to quality professional development if they are going to experience success. School districts must provide funding for extra training. The hard work of teaching out of field must be acknowledged and intense, ongoing focused training must be provided by school districts at both building and district levels. School districts must provide districtwide curriculum-based professional development to ensure that all teachers are receiving quality professional development.

3. If out of field teachers are going to experience success, they must have support. Mentors and mentees must have time to observe and be observed on a regular basis. Mentees must be able to observe expert teachers who are skilled in their same content area. Building administrators must provide time for mentors and out-of-field teachers to meet and have meaningful discourse about their observations. These teachers must have time to unwrap curriculum and explore strategies that will benefit the students they are charged to teach. Out-of-field 
teachers would also benefit from observations and feedback at the district level from curriculum coaches and department heads.

\section{Implications for future research}

As has been previously noted the mission and purpose of any school is the success and achievements of its students. All efforts must be directed to improving student achievement. The person who is ultimately responsible for this task is the teacher. What the teacher knows and does in the classroom is the determining factor in improving student achievement. Substantial evidence shows that teacher qualification is linked to student achievement. Out-of-field teachers require rigorous training if they are going to be assigned to teach classes for which they are not qualified. These teachers teach outside of their field of study or expertise; this makes the need for content area professional development crucial to their success (Ingersoll, 2002, Jacob, 2007).

Based on the findings of this study, the researcher offers the following recommendations:

1. Conduct the qualitative study using a larger sample group from urban schools statewide. Because curriculum should mirror itself statewide, research on a larger scale should reflect the impact of out-of-field teaching on student achievement statewide. A statewide study would allow for discourse among school leaders on a larger level in an effort to improve teacher training and student achievement statewide. This current study used a sample group from only one urban school setting. 
2. Conduct the study using sample groups from urban schools across the nation. A comparison of national data could inform practices in teacher training for inservice teachers, as well as professional development and student achievement. A study on a nationwide scale could open the door for colleges and universities to partner with school districts to provide quality teacher development support systems. Furthermore, a nationwide study can provide an opportunity for school districts across the nation to collaborate and align curricula so that all students have an equal chance at a quality education.

3. Conduct a mixed methods study that includes teacher and student perception data as well as student assessment data. Input from secondary students as it relates to their perceptions of the education they are receiving could prove vital in discussions about curriculum and the teacher's ability to reach all learners. The quantitative portion of the study could be analyzed and checked for correlations in the data.

\section{Reflections and Conclusion}

Conducting this study unveiled some loopholes in hiring and assignment practices that I believed had been disallowed by the state commission on education. The No Child Left Behind Act states that parents must be informed if their child is being taught by a teacher who is not certified or who is not highly qualified. This act was developed to ensure that schools were staffed with highly qualified individuals who could deliver the highest level of teaching for all students. However, because the decision of how to assign teachers is left to the discretion of the school principal, who, due to staffing, teacher 
shortages, and unequal access to qualified teachers often assigns a teacher to teach classes outside their area of expertise.

Teaching is complexed work. "Few people would want a cardiologist to deliver babies or real estate lawyers to defend criminal cases, chemical engineers to design bridges, or sociology professors, to teach English"(Ingersoll, R., 2001 P.45). We would not want this because we assume that these professions require certain skills and expertise. Therefore specialization is necessary. Yet we do not hold the same assumptions when it comes to out-of-field teaching. On the contrary, our assumptions hold that teaching requires far less skill or expertise and therefore specialization is not necessary (Ingersoll, 2001).

This study could inform practices in hiring and teacher assignment to ensure that all students, particularly those in high-poverty, high minority areas receive the same quality of education as their counterparts in more affluent areas. This study could also inform educational policies on state and national with regards to teacher certification standards and rigorous requirements for teaching. 


\section{References}

Allington, R., (2003). The six ts of effective elementary literacy instruction. Retrieved from www.readingrockets.org/article.php? ID $=413$

American Evaluation Association Guiding Principles for Evaluators (2004)

\section{http://www.eval.org/publications/aea06.GPBrochure.pdf}

Archibald, S., Coggshall, J., Croft, A., \& Goe, L., (2017). High quality professional development for all teachers: effectively allocating resources. National Comprehensive Center for Teacher Quality. 1-32.

Bales, B., \& Saffold, F., (2011). A new era in the preparation of teachers for urban schools: linking multiculturalism, disciplinary-based content, and pedagogy. Urban Education 46, 953-974.

Berry, B., (2001). No shortcuts to preparing good teachers. Educational Leadership 58 8), 32-36.

Bolman, L. \& Deal, T., (4 ${ }^{\text {th }}$ ed.) (2008). Reframing Organizations: Artistry Choice, and Leadership. San Francisco, CA: Jossey and Bass.

Borko, H. (2004). Professional development and teacher learning: mapping the terrain. Educational Researcher. 33(8), 3-15.

Britton, E., Paine, L., Pimm, D., \& Raizen, S. (Eds.). (2003). Comprehensive teacher induction: Systems for early career learning. Washington, D.C.: Kluwer Academic Publishers and WestEd.

Brown, K.M. (2008). Doing all the right things: teacher retention issues. Educational Leadership. 11(1)10-17.

Collins, J. C. (2001). Good to great: Why some companies make the leap ... and others 
don't. New York, NY: Harper Business.

Cook, L., “U.S. Education Still Separate and Unequal.” U.S. News and World Report. Jan. 28, 2015:1

Creswell, J., (2 ${ }^{\text {nd }}$ ed.) (2007) Qualitative Inquiry and Research Design. Thousand Oaks, CA: Sage Publications, Inc.

Creswell, J., (3 ${ }^{\text {rd }}$ ed.) (2009). Research Design: Qualitative, Quantitative, and Mixed Methods Approaches. Thousand Oaks, CA: Sage Publications, Inc.

Darling-Hammond, L., (2001). The challenge of staffing our schools: how do states and districts attract, train, and retain high-quality teachers without ignoring shortage areas or student needs? Educational Leadership (5) 12-17.

Darling-Hammond, L., (2006). Securing the right to learn: Policy and practice for powerful teaching and learning. Educational Researcher, 35: 13-24

Darling-Hammond, L., \& Youngs, P. (2002). Defining “highly qualified teachers": What does scientifically-based research actually tell us? Educational Researcher, 31(9), 13-25.

Education Week (2000). Quality counts: A report on education in the 50 states. Washington, DC.

Ellerson, N., (2012). School Budgets 101. American Association of School Administrators. 1-15.

Futernik, K., (2010). Incompetent teachers or dysfunctional systems. Kappan. 9(2), 5964. 
Garet, M., Porter, A., Desimone, L., Birman, B., Yoon, K., (2001). What makes professional development effective? Results from a national sample of teachers. American Educational Research Journal, 38(4), 915-945.

Geringer, J., (2003). Reflections on professional development: toward high-quality teaching and learning. Phi Delta Kappan, 84(5), 373-375,380.

Giorgi, A. (2009). The descriptive phenomenological method in psychology: A modified Husserlian approach. Pittsburgh, PA: Duquesne University Press.

Haycock, K., (1998) Good Teaching Matters: How well-qualified teachers can close the gap. Thinking K-16.3(2) 1-31.

Haycock, K., (2002-2003) Toward a fair distribution of teacher talent. Educational Leadership. 60(4), 11-15.

Heck, R.H., (1998) Conceptual and methodological issues in investigating principal leadership across cultures. Peabody Journal of Education. 73(2) 51-80.

Hersey, P., Blanchard, K.H, and Johnson, D.E., (2007).Management of Organizational Behavior: Leading Human Resources, New York, NY: Prentice Hall.

Ho, Angela, (2000). A conceptual change to staff development: a model for program design. International Journal for Academic Development. 5(1) 30-41

Hobbs, L. (2013). Teaching 'out-of-field' as a boundary-crossing event: Factors shaping teacher identity. International Journal of Science and Mathematics Education, $11(2), 271-297$.

Hobbs, L. (2015). Too many teachers teaching outside their area of expertise. The 
Conversation (1-3)https://theconversation.com/too-many-teachers-teachingoutside-their-area-of-expertise-39688

Ingersoll, R. (1999), “The problem of underqualified teachers in American Secondary Schools. Educational Researcher. 28(2) 26-37.

Ingersoll, R. (2000), The sources of out-of-field teaching. Out-of-Field Teaching. ERIC Digest Eric Clearinghouse on Teaching and Teacher Education, Washington D.C. Ingersoll, R. (2001). Misunderstanding the problem of out-of-field teaching. Educational Researcher, 30(1) 21-22.

Ingersoll, R. (2002), Out-of-field teaching, educational inequality, and the organization of schools: an exploratory analysis. Center for the Study of Teaching and Policy.

Ingersoll, R.M. (2002). The teacher shortage: A case of wrong diagnosis and wrong prescription. NASSP Bulletin, 86(631), 16-30.

Ingersoll, R. (2003), Out-of-field teaching and the limits of teacher policy. Center for the Study of Teaching and Policy and the Consortium for Policy Research in Education, University of Pennsylvania.

Ingersoll, R. and Strong, M., The Impact of Induction and Mentoring Programs for Beginning Teachers: A Critical Review of the Research. Review of Educational Research June 2011 81: 201-233, 1-32

Isreal, M., Kamman, M., McCray, E., and Sindelar, P. (2014). The interplay among professional assistance, emotional support and education. Exceptional Children. 81(1) 454-63.

Jacob, B. (2007), The challenges of staffing urban schools with effective teachers. The Future of Children. 17(1), 129-153. Spring.

Jerald, C., \& Ingersoll, R. (2002), All talk and no action: putting an end to out-of-field 
teaching. University of Pennsylvania Scholarly Commons. 1-14.

Johnson, S.M. (2004). Finders and Keepers: Helping new teachers survive and thrive in our schools. San Francisco, CA: Jossey-Bass.

Lankford, H., Loeb, S., and Wyckoff, J., (2002).Teacher Sorting and the Plight of Urban Schools: A Descriptive Analysis. Educational Evaluation and Policy Analysis. 24: 37-62.

Laura Lippman, Shelley Burns, Edith McArthur, (1996). Urban schools: The challenge of location and poverty. National Center for Education Statistics. Washington, D.C.

Leithwood, Seashore-Louis, Anderson and Wahlstrom, (2004). How leadership improves student learning. The Wallace Foundation. 3-90

Leland, C., and Murtadha, K, (2011). Cultural discourse on the frontline: preparing and retaining urban teachers. Urban Education. 46:895-912.

Luft, J. A., \& Cox, W. E. (2001). Investing in our future: A survey of support offered to beginning secondary science and mathematics teachers. Science Educator, 10(1), $1-9$.

Moustakas, C. (1994). Phenomenological research methods. London, UK: Sage. National Center for Education Statistics. (2000). Monitoring quality: An indicators report. Washington, D.C.

National Commission on Teaching and America's Future. (2002). Unraveling the "teacher shortage" problem: Teacher retention is key. Washington, D.C.

Olsen, B., and Sexton, D., (2009), Threat rigidity, school reform, and how teachers view 
their work inside current education policy contexts. Americano Educational Research Journal, 46(1), 9-44. Retrieved from University of Missouri-Columbia on March 26, 2010.

Peske, H.G., and Haycock, K., Teaching Inequality, how poor and minority students are shortchanged on teacher quality. The Education Trust, 2006

Podgursky, M., (2005). Teacher licensing in U.S. public schools: the case for simplicity and flexibility. Peabody Journal of Education. 80(3), 15-43.

Putnam, R. \& Borko, H. (2000). What do new views of knowledge and thinking have to say about research on teacher learning? Educational Researcher, 29(1), 4- 15.

Riggs, Liz, (2013). Why do teachers quit? And why do they stay? The Atlantic,1-7. Routes to certification 2016. https://dese.mo.gov/educatorquality/certification/routes-

Rowan, B. (2002). What Large-Scale, Survey Research Tells Us About Teacher Effects on Student Achievement: Insights From the Prospects Study of Elementary Schools. Ann Arbor: University of Michigan (unpublished).

Russo, Pat, (2004). "What makes any school an urban school?" Coordinator of the Center for Urban Schools.

Sawchuck, Stephen, (2017). Full cost of professional development hidden. Education Week, 30(11)14-16.

Seidman, Irving, ( $3^{\text {rd }}$ ed.)(2006) Interviewing as Qualitative Research: A Guide for Researchers in Education and the Social Sciences. New York, NY. Teachers College Press.

Tell, C., (2001). Making room for alternative routes. Educational Leadership, 58(8), 38- 
41.

Wallace Foundation (2017). Turning Around the Lowest-Performing Schools: The Role of Districts - Research Findings to Support Effective Educational Policy Making, $1-5$.

Wang, J., Odell, S., \& Schwille, S., (2008). Effects of teacher induction on beginning teachers' teaching: a critical review of the literature. Journal of Teacher Education. 59, 132-152.

Wong, H., (2004). Induction programs that keep new teachers teaching and improving. NASSP Bulletin, 88, 41-58.

Wynn, S., Carboni, L.W., Patall, E. (2007). Beginning teachers’ perceptions of mentoring, climate, and leadership: promoting retention through learning communities’ perspective. Leadership and Policy in Schools 6:209-229.

Yonezawa, S., Jones, M., \& Robb-Singer, (2011). Teaching resilience in urban schools: The importance of technical knowledge, professional community, and leadership opportunities. Urban Education. 46:913-930. 


\section{Appendix A}

Interview questions for out-of-field teachers:

1. Is the professional development you receive relevant to the work you perform in the classroom?

2. What do you think your district can do to help you to be more effective in your out-of-field teaching experience?

3. In your opinion, what more should your district do to prepare you for the subjects you have been assigned to teach?

4. What does the district do to ensure that you have adequate training? Is this sufficient?

5. How does the district follow up with you to ensure that you are successful in implementing professional development?

6. How do you see your role in ensuring the sustainability of professional development?

7. Is it difficult to buy-in to the professional development provided by your district? Explain.

8. What do you do when you perceive the training or professional development you receive to be ineffective?

9. Does the district solicit your opinion or the opinion of teachers in your district when choosing professional opportunities?

10. How does buy-in or the lack of effect the sustainability of teacher development support systems in your school? 
11. What steps do you take to ensure that teacher development support systems benefit your efforts in the classroom?

12. How do you collaborate with your mentor to receive the most benefits from professional development?

13. Is there ample time for you to meet with your mentor for guidance, support, collaboration and assistance with implementation of professional development strategies?

14. What role do you perceive your mentor plays in your professional growth?

15. Does your school principal provide time for you to meet with, observe as well as opportunities to be observed by your mentor? 
Questions for mentors of out-of-field teachers

1. Is the professional development received relevant to the work you perform in the classroom?

2. What do you think your district can do to help new teachers be more effective in their out-of-field teaching experience?

3. In your opinion, what more should your district do to prepare teachers for the subjects they have been assigned to teach?

4. What does the district do to ensure that out-of-field teachers have adequate training? Is this sufficient?

5. How does the district follow up with you and your mentee to ensure that you both are successful in implementing professional development?

6. How do you see your role in ensuring the sustainability of professional development?

7. Is it difficult to buy-in to the professional development provided by your district? Explain.

8. What do you do when you perceive the training or professional development you receive to be ineffective?

9. Does the district solicit your opinion or the opinion of teachers in your district when choosing professional opportunities?

10. What steps do you take to ensure that teacher development support systems benefit your work with your mentee teacher?

11. How do you collaborate with your mentee so that he/she receives the most benefits from professional development? 
12. Is there ample time for you to meet with your mentee to provide guidance, support, collaboration and assistance with implementation of professional development strategies?

13. What role do you play in your mentee's professional growth?

14. Does your school principal provide time for you to meet with and observe as well as opportunities to be observed by your mentee? 


\section{Appendix B}

Please participate. Thank you in advance and/or thank you if you have already replied. Your participation is greatly appreciated.

\section{University of Missouri at Columbia}

\section{Recruitment Statement for Research Participation}

1. Niketia L. Coleman, Doctoral student and Principle Investigator is inviting you to participate in this research study.

2. The title of this study is Perceptions of the Sustainability of Urban Teacher Quality Support Systems. I am Niketia Coleman and I am interested in studying how urban, out-of-field teachers and mentors perceive the quality of their school districts' professional development efforts through the teacher lived experiences with professional development support systems and their impact on teacher retention in urban schools. This study will identify the support practices and professional development program opportunities of urban Missouri school districts under pressure from the State to improve student achievement and raise standardized test scores. This study seeks to analyze those practices and programs and their sustainability as perceived by teachers.

My rationale for choosing this topic is that there is a growing number of out-of-field teachers in hard to staff urban schools with large minority populations. Because these teachers are teaching outside their field of certification of qualification it is important that they receive extensive professional development and training to ensure their effectiveness in the class room. This study examines the perceptions of out-of-field teachers and how those perceptions shape the effectiveness and sustainability of quality support systems. Examination of the staff development practices of urban districts will focus on the commitment of under-qualified and struggling staff members to seek coursework, professional development and training to become more qualified as well as the commitment of the school and district leaders to provide support for these individuals. Furthermore, this study seeks to evaluate the practices and strategies teachers use to understand and execute their responsibilities, organize their work and attain objectives. This study will explore resources and external activities sought by school districts and individuals to enhance teacher performance.

It is my perception that there is a significant potential for this study to affect the broader educational community such as underperforming districts meeting state, (Missouri School Improvement Plan) and national requirements, (Every Student Succeeds Act).

3. Your willingness to participate would only require about one hour and thirty minutes to conduct an audiorecorded focus group interview/individual interview during the period of August 21, 2017, through September 22, 2017. In respect for each other, we ask that only one individual speak at one time in the group and that responses made by all participants be kept confidential. Your participation is voluntary and there is no penalty if you do not participate. If you are willing to participate in this study, please sign and return the enclosed informed consent form in the self-addressed, stamped envelope. A response by August 21, 2017, is greatly appreciated. Once I receive your response, I will follow up to arrange a focus group interview/individual interview. If you are unable to participate in this study, an e-mail response declining participation would also be appreciated. Regardless of whether you choose to participate, please let me know if you would like a summary of my findings.

4. There are no risks involved in the participation in this study because no personally identifiable information will be collected, you do not have to answer questions that make you feel uncomfortable.

5. The results of this study may be published in educational research journals or presented at professional conferences. However, your name and identity will not be revealed and your record will remain anonymous. The interview information is Anonymous/de-identified: data contains no, identifiers, including code numbers that investigators can link to individuals. 
6. Participation in this study will not benefit you directly. However, you will have the opportunity to think introspectively and reflect on your own professional practice in ways you may not have considered before. Your participation may benefit others by having the opportunity to explore how their peers prepared for their leadership roles and use said information to advance their own professional growth and practice. Additionally, the end result would potentially be more informed school principals and school districts in how they support teachers to promote high quality mathematics instruction for all students regardless of their background and socioeconomic status.

7. You can choose not to participate. If you decide not to participate, there will not be a penalty to you or loss of any benefits to which you are otherwise entitled. You may withdraw from this study at any time. 
Niketia Coleman has been an educator for 22 years. She has served as a middle school seventh and eighth grade Language Arts and Social Studies teacher. She taught at the elementary level where she served on the building leadership team. Ms. Coleman has also served as Small Learning Community (SLC) coordinator at the middle school level. Niketia Coleman served as an assistant principal of Westview Middle School in the Riverview Gardens School District for three years. For the past four years she has served as a seventh grade Language Arts teacher in the Hazelwood School District.

Early in her career Ms. Coleman worked with the Upward Bound Program at Harris-Stowe State University where she helped prepare high school students for college. She taught essay writing, as well as, SAT and ACT prep classes. She assisted students in completing college and scholarship applications and coordinated college visits throughout the United States and Canada.

Niketia Coleman earned a Bachelor's of Science Degree in Elementary Education with certifications in middle school language arts and social studies from Harris-Stowe State University. She earned a Master's Degree in Educational Administration and an Educational Specialist Degree also in the field of Educational Administration from the University of Missouri St. Louis. Ms. Coleman is passionate about teaching children to think critically, communicate effectively and work cooperatively with others so that they will be able to compete in the global society. 